\title{
Archeological Excavation and Reburial of Historic Graves in the Oscar Abstein Cemetery (41HR976), Harris County, Texas
}

Cory Julian Broehm

Douglas K. Boyd

Martha Doty Freeman

Follow this and additional works at: https://scholarworks.sfasu.edu/ita

Part of the American Material Culture Commons, Archaeological Anthropology Commons, Environmental Studies Commons, Other American Studies Commons, Other Arts and Humanities Commons, Other History of Art, Architecture, and Archaeology Commons, and the United States History Commons

Tell us how this article helped you.

This Article is brought to you for free and open access by the Center for Regional Heritage Research at SFA ScholarWorks. It has been accepted for inclusion in Index of Texas Archaeology: Open Access Gray Literature from the Lone Star State by an authorized editor of SFA ScholarWorks. For more information, please contact cdsscholarworks@sfasu.edu. 


\section{Archeological Excavation and Reburial of Historic Graves in the Oscar Abstein Cemetery (41HR976), Harris County, Texas}

\section{Licensing Statement}

This is a work produced for the Texas Department of Transportation (TxDOT) by the report producer. TxDOT and the report producer jointly own all rights, title, and interest in and to all intellectual property developed under TXDOT's contract with the report producer. The report may be cited and brief passages from this publication may be reproduced without permission provided that credit is given to both TXDOT and the report producer. Permission to reprint an entire chapter, section, figures or tables must be obtained in advance from either the Supervisor of the Archeological Studies Branch, Environmental Affairs Division, Texas Department of Transportation, 125 East 11th Street, Austin, Texas, 78701 or from the report producer. 


\title{
ARCHEOLOGICAL EXCAVATION AND REBURIAL
} OF HISTORIC GRAVES IN THE OSCAR ABSTEIN CEMETERY (41HR976), HARRIS COUNTY, TEXAS

\author{
by \\ Cory Julian Broehm, \\ Douglas K. Boyd, \\ and \\ Martha Doty Freeman \\ Principal Investigator: Douglas K. Boyd \\ REPORT OF INVESTIGATIONS, NO. 140 \\ Prewitt and Associates, Inc. \\ Cultural Resources Services \\ Austin, Texas
}

ARCHEOLOGICAL STUDIES PROGRAM, REPORT NO. 64

Texas Department of Transportation

Environmental Affairs Division

Austin, Texas

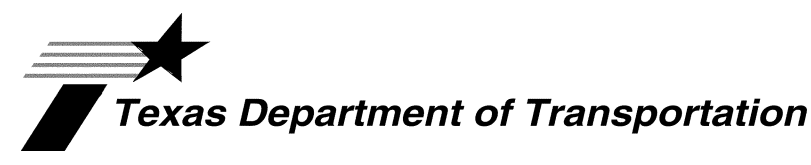

May 2004

TEXAS ANTIQUITIES PERMIT NO. 3244 


\title{
ARCHEOLOGICAL EXCAVATION AND REBURIAL OF HISTORIC GRAVES IN THE OSCAR ABSTEIN CEMETERY (41HR976), HARRIS COUNTY,TEXAS
}

\author{
Copyright @ 2004 \\ Texas Department of Transportation (TxDOT)
}

TxDOT and Prewitt and Associates, Inc., jointly own all rights, title, and interest in and to all data and other information developed for this project under Contract No. 573XXSA001. Brief passages

from this publication may be reproduced without permission provided that credit is given to TxDOT and Prewitt and Associates. Permission to reprint an entire chapter, section, figures or tables must be obtained in advance from the Supervisor of the Archeological Studies Program, Environmental Affairs Division, Texas Department of Transportation,

125 East $11^{\text {th }}$ Street, Austin, Texas, 78701. Copies of this publication have been deposited with the Texas State Library in compliance with the

State Depository Requirement.

jointly published by the

Texas Department of Transportation

Environmental Affairs Division

Archeological Studies Program

Owen Lindauer, Ph.D., Supervisor Archeological Studies Program, Report No. 64

and

Prewitt and Associates, Inc.

Cultural Resources Services Austin, Texas

Reports of Investigations No. 140

Contract \#573XXSA001

Printed at Morgan Printing in Austin, Texas 


\section{TABLE OF CONTENTS}

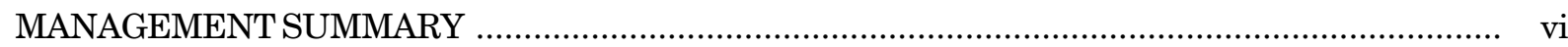

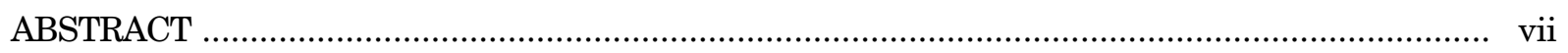

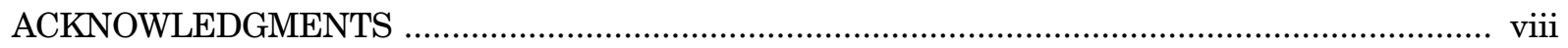

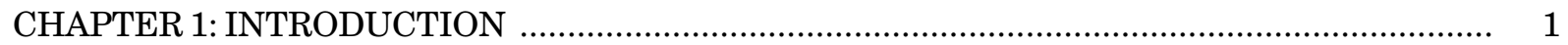

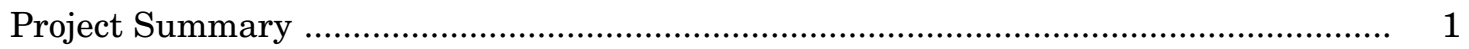

Location and Environmental Setting ......................................................................... 2

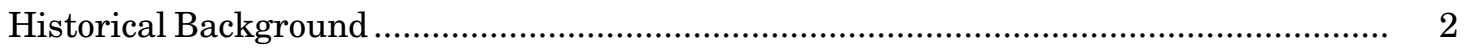

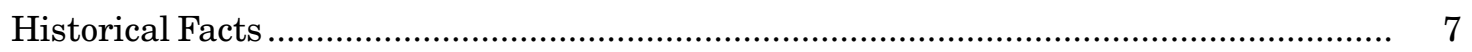

CHAPTER 2: METHODS AND RESULTS OF INVESTIGATION .......................................... 9

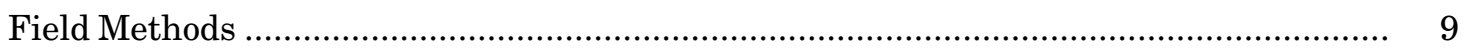

Re-location of Unmarked Graves ........................................................................... 9

Archeological and Bioarcheological Examinations ................................................ 16

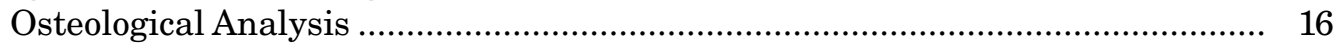

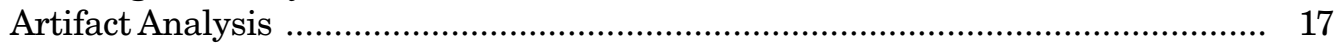

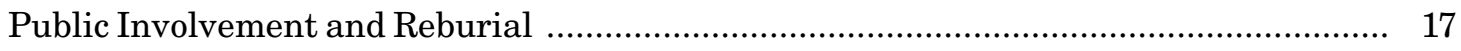

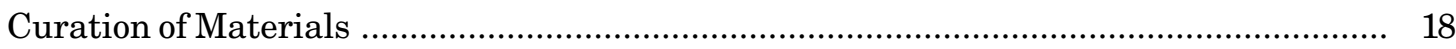

CHAPTER 3: BURIAL DESCRIPTIONS AND ANALYSIS ................................................. 19

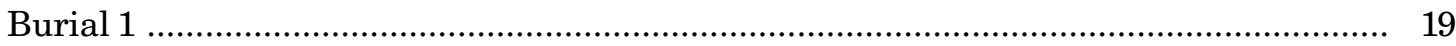

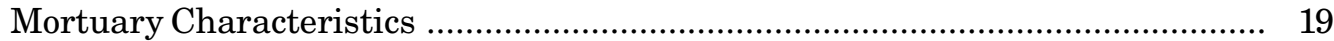

Osteological Characteristics .......................................................................... 20

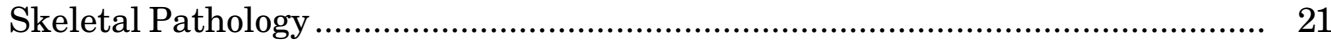

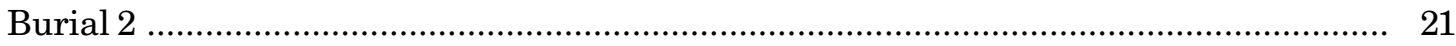

Mortuary Characteristics ......................................................................... 21

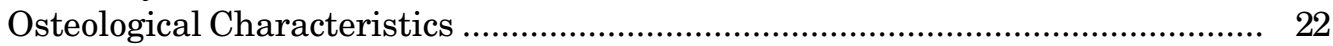

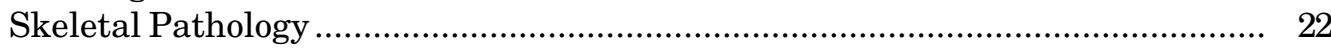

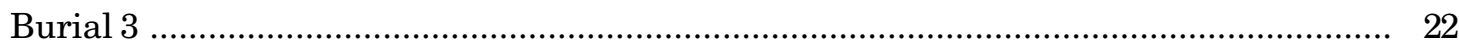

Mortuary Characteristics ........................................................................... 22

Osteological Characteristics .................................................................... 23

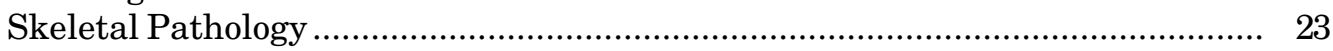

CHAPTER 4: ARCHEOLOGICAL AND BIOARCHEOLOGICAL ANALYSIS .............................. 25

Mortuary Artifacts and Personal Items ................................................................. 25

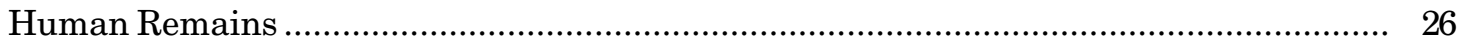

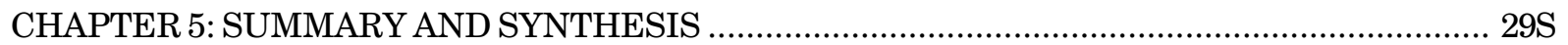




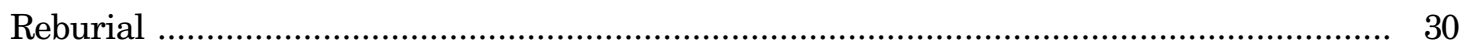

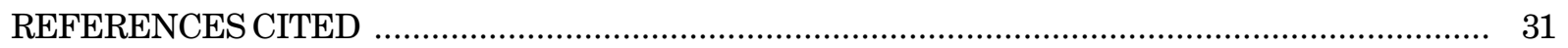

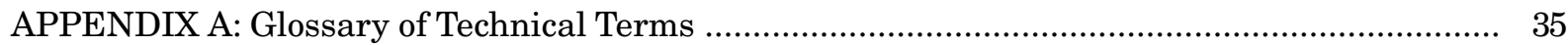

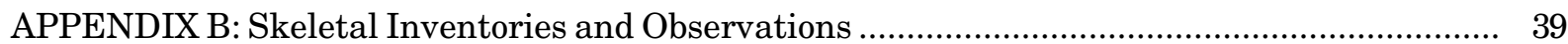




\section{LIST OF FIGURES}

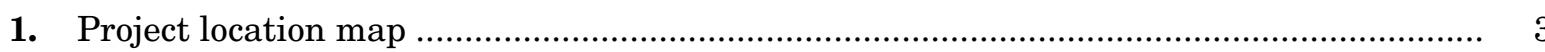

2. Location of Abstein Cemetery on Lot 6 of the subdivision of the Joel Wheaton Survey .... 5

3. Deed record mentioning three graves in the Missouri, Kansas and Texas Railway

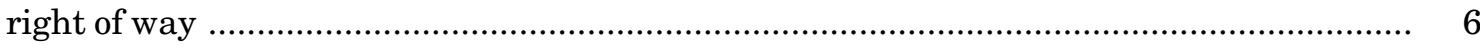

4. Photograph of eastern grave marker at Abstein Cemetery …...................................... 10

5. Photograph of Abstein Cemetery before the archeological excavations began,

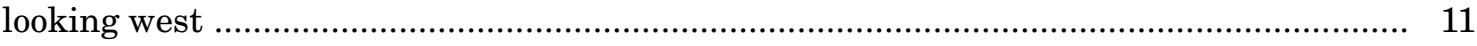

6. Construction planview of proposed concrete retaining wall to protect

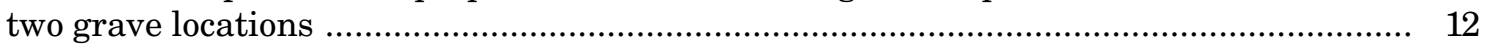

7. Planview of grave markers on surface and buried plinths found during trenching ............ 13

8. Planview and profile of re-located grave shafts in Abstein Cemetery ............................... 14

9. Photograph of excavation block at Abstein Cemetery, looking east with Interstate Highway 10 in the background ......................................................... 15

10. Bone buttons from Burial 1 ................................................................................. 20 


\section{MANAGEMENT SUMMARY}

This report documents the exhumation and reburial of three historic graves within the right of way of Interstate Highway 10 (IH-10) near the intersection of Eldridge Drive. Called the Eldridge or Oscar Abstein Cemetery, historic research indicated that three to four graves probably existed near station marker 581+75 within the area of improvements that the Texas Department of Transportation (TxDOT) proposed to IH-10. TxDOT's Archeological Studies Program, Environmental Affairs Division, prepared a planning document entitled: "Exhumation and Reinterment Plan, IH-10, CSJ: 0271-07-247, Eldridge Cemetery" and contracted with Prewitt and Associates, Inc., of Austin, Texas, to conduct the necessary investigations. Work performed under Contract No. 573XXSA001, Work Authorization No. 57311SA001, included a mechanical grave search, excavation and removal of burial remains, on-site analysis, and reburial. These tasks were accomplished between November 18 and 21, 2003. No collections were made.

Gradall scraping and subsequent hand excavations exhumed the remains of four individuals

in three separate graves. Analysis of these remains, as well as historical documentation, identifies these people as:

Burial 1 Unidentified adult, probably female, age 30 to 40 years.

Burial 2 Unidentified, probably adult, indeterminate sex and age.

Burial 3 Disarticulated remains of Oscar Abstein, a 38-year old male, and an unidentified child of indeterminate sex. These two died in 1884 and were reburied at this location in 1892.

All remains associated with these graves were reinterred in the Washington section of the Washington-Glenwood Cemetery, managed by Glenwood Cemetery, Inc., at 2525 Washington Avenue in Houston. The remains were placed together in a single plot designated as Section I, Lot 19, Space 6, West Half, within Washington Cemetery. 


\begin{abstract}
Proposed improvements to Interstate Highway 10 (IH-10) in Harris County led the Texas Department of Transportation to contract Prewitt and Associates, Inc., to conduct an archeological investigation of a small cemetery near the intersection of $\mathrm{IH}-10$ and Eldridge Parkway in west Houston. Historic research in 2002 revealed that Oscar Abstein and a small child died in 1884 and were buried near two older but unidentified graves. Records indicate that Abstein's grave was moved in 1892, when the Missouri, Kansas and Texas Railway was built, and various historic maps and documents refer to the presence of two to four graves in the project location. Archeological investigations in November 2003 located and exhumed the remains of four individuals in three separate graves. Onsite analysis revealed one grave contained remains of a probable 30 to 40 year old female, one contained remains of a adult of indeterminate age and sex, and the third grave contained the disarticulated remains of Oscar Abstein and an unidentified child. The remains from all three burials were reinterred in the Washington section of Washington-Glenwood Cemetery near downtown Houston.
\end{abstract}




\section{ACKNOWLEDGMENTS}

For the Abstein Cemetery project, Douglas K. Boyd served as principal investigator, but Cory Julian Broehm was the project archeologist and physical anthropologist-osteologist. The field crew members were Prewitt and Associates, Inc. (PAI), employees Hedy Justus and Jennifer K. McWilliams, as well as Angela Tiné from GeoMarine Inc., of Plano, Texas. McWilliams also served as project photographer. Jane Sevier edited this report, and Brian Wootan prepared the illustrations.

TxDOT's Archeological Studies Program, Environmental Division, in Austin oversaw PAI's work. Dr. Owen Lindauer (program supervisor) and archeologist Allen Bettis Jr. organized and directed this project. Bettis was present during the entire field project, and his advice and support are greatly

appreciated. TxDOT personnel from the Houston District, West Harris Maintenance Office, assisted PAI in many ways. Maintenance supervisor Scott Sholz, project manager Lance Olenius, and Stanley Cooper helped schedule the work and make logistical arrangements. Willy Gomez operated the Gradall during the search for the graves, and his skillful manipulation of the machine was essential. Two other people helped oversee the PAI investigations-Greg Olfield, project manager for the Katy Freeway Reconstruction Program, and Forbie Harper, chief inspector for Parsons, Brinkerhoff, Quade \& Douglas, Inc. Richard Ambrus, general manager of Glenwood Cemetery, Inc., arranged and assisted in the reinterments of the historic graves in the Washington Cemetery. 


\section{INTRODUCTION}

\section{PROJECT SUMMARY}

Abstein Cemetery-a small aggregation of mostly unmarked graves rather than a formal cemetery-is named for Oscar Abstein, the only identified person buried within it. Almost nothing is known of the life of Oscar Abstein-more seems to be known about the fate of his remains after he died. Oral history suggests that in 1884, Oscar Abstein and a small child were travelling through the Houston area, near the west edge of Harris County. They both became ill and died, Abstein on July 10 of that year. Both were apparently buried on the property of the Gastmann family near what is now the northwest intersection of Eldridge Parkway and the westbound frontage road of Interstate Highway 10 (IH-10). Archival records indicate two unidentified graves were already to be found in the vicinity where Abstein and the child were buried.

Abstein's grave was moved nearer the former two graves sometime in late 1892 or after, when the Missouri, Kansas and Texas Railway Company (Katy) acquired some of the Gastmann property to lay railroad tracks. The right of way acquired by the railroad contained the Abstein grave, and the deed (Harris County, Deed Record 64:66-67) required the railroad to move his grave to be near the other two graves, but no specific mention was made of the child's grave. This location became known as Abstein Cemetery or Eldridge Cemetery. Before the project described in this report began, the site was marked by two cement blocks, lying flat on the surface and encasing broken fragments of Oscar Abstein's headstone, along with two recently placed wooden crosses, ostensibly marking locations of two graves.

Houston witnessed significant growth from the late nineteenth century through the twentieth, becoming one of the major metropolitan areas of the United States. The city grew to encompass Abstein Cemetery within its city limits. The original State Highway No. 73, which passed alongside the site of the graves, developed into a major artery for the city and later became U.S. Highway 90 and, eventually, Interstate Highway 10. After the Federal-Aid Highway Act passed in 1956, construction of IH-10 in the 1960s necessitated building of a 10-ft-high, 2 -ft-thick concrete retaining wall between the westbound access road and the graves. This wall has served to protect and partially enclose the cemetery. Because the greater Houston area continues to grow in the twenty-first century, the Texas Department of Transportation (TxDOT) is now involved in widening and upgrading IH10. Historical research and the presence of the above-mentioned grave markers indicated that the graves were still present within the right of way. Because the Abstein grave and any other graves in the right of way would be disturbed by this construction, in $2003 \mathrm{TxDOT}$ contracted with Prewitt and Associates, Inc. (PAI), to locate any graves within the right of way and exhume, analyze, and rebury the remains. The fieldwork was conducted from November 17 to November 21, 2003 , and this report describes the methods and results of the project.

PAI archeologists located three graves containing the remains of four people within the right of way. The three graves (designated as Burials 1, 2, and 3) were excavated, the mortuary and human remains were analyzed on site, and the remains from each grave were placed inside individual reburial boxes. When the archeological work was complete, PAI archeologists took the boxes to the Washington Cemetery 
in Houston, where they were reburied on November $21,2003$.

\section{LOCATION AND ENVIRONMENTAL SETTING}

Abstein Cemetery is situated in urban west Houston, Texas, within Harris County and approximately $16 \mathrm{~km}$ (10 miles) east of the point at which Harris, Waller, and Fort Bend Counties come together (Figure 1). The cemetery is bordered on the south by the westbound frontage road of IH-10 and on the north by an abandoned railroad bed of the Katy. As noted above, the graves are on a surface well above and separated from the frontage road by a concrete retaining wall that is $3 \mathrm{~m}$ (10 ft) high. Old Katy Road runs east-west just north of the railroad. Approximately $40 \mathrm{~m}(131 \mathrm{ft})$ to the east of the cemetery is Eldridge Parkway. Based on the work by PAI archeologists, the three graves that make up Abstein Cemetery are contained within an area of approximately $8 \times 4 \mathrm{~m}$.

Abstein Cemetery is situated on the western Gulf section of the Coastal Plain. The cemetery is between Turkey Creek, approximately $1 \mathrm{~km}$ (.60 miles) to the east, and the channelized Bear Creek, approximately $0.5 \mathrm{~km}$ (.30 miles) to the west. Approximately $1.6 \mathrm{~km}(1 \mathrm{~m})$ southsouthwest of Abstein Cemetery, these creeks drain into Buffalo Bayou, which drains into Galveston Bay to the east. The Brazos River is approximately $20 \mathrm{~km}$ (12.4 miles) south of the Abstein graves. Elevations in the project area range from 26.0 to $27.5 \mathrm{~m}$ ( 85 to $90 \mathrm{ft}$ ) above mean sea level.

The late Pleistocene Beaumont Formation underlies the site. The Beaumont Formation was deposited by fluvial and deltaic processes (Aronow 1976:45), possibly originating from the Pleistocene ancestors of the San Jacinto and Trinity Rivers (Bureau of Economic Geology 1968). Aris series soils are mapped in the vicinity of Abstein Cemetery (United States Department of Agriculture 1976:10-11). These deep, nearly level soils are found on upland prairies. In a representative profile, the upper $53 \mathrm{~cm}$ (21 inches) was a grayish brown to dark grayish brown fine sandy loam, becoming a gray sandy clay loam at 53 to $71 \mathrm{~cm}$ (21 to 28 inches), and then a light gray to dark gray clay in the remainder. Mottling was common throughout the profile, starting as yellowish brown in the upper part of the profile and becoming more red to yellowish red (United States Department of Agriculture 1976:47). The upper $80 \mathrm{~cm}$ (31.5 inches) of this profile was truncated at Abstein Cemetery, however, because of construction grading associated with highway upgrading and subsequent deposit of road fill over the graves.

\section{HISTORICAL BACKGROUND}

In February 2002, TxDOT contracted with Prewitt and Associates, Inc. (PAI), to check historical records and document reported burials within the existing right of way $\mathrm{IH}-10$ at the northwest intersection of Eldridge Parkway and the IH-10 westbound frontage road in western Harris County. These burials are called the Abstein Cemetery or Eldridge Cemetery. Historian Martha Doty Freeman (2002) conducted the research to document the burials. Deed and tax records were reviewed, as were maps at the Houston Public Library. Oral interviews were conducted with Harris County genealogist Trevia Wooster Beverly and a representative of the Alief Cemetery Association, and interviews that TxDOT personnel conducted were reviewed. The information presented below was derived from the previous research by Freeman (2002), and much of it is presented verbatim.

Deed and tax records, as well as maps, indicate the site designated as Abstein Cemetery is situated on the eastern edge of the Joel Wheaton Survey, a league and labor that runs north-south and is traversed by Buffalo Bayou. Wheaton and his family made their home on the survey. By early 1839 , he had died, leaving a widow, Elizabeth G. Wheaton, and five children (Harris County, Probate Records C:234-237).

In 1848, several of Wheaton's heirs applied to the court for a partition and distribution of the assets of the estate (Harris County, Probate Records C:234-237). The Wheaton grant was surveyed, and the court ordered it divided into six shares or lots. Share 6 , situated along the east line of the Wheaton Survey, went to Argive H. Wheaton Brookshire, a daughter of Joel and Elizabeth Wheaton (Harris County, Probate Records H:453-461). Share 6 is the location of Abstein Cemetery and is shown as Lot 6 in Figure 2.

Soon after receiving her share, Argive Brookshire and her husband, Archille, sold the 460 1/2 acres to Caspar Habermacher (Harris 


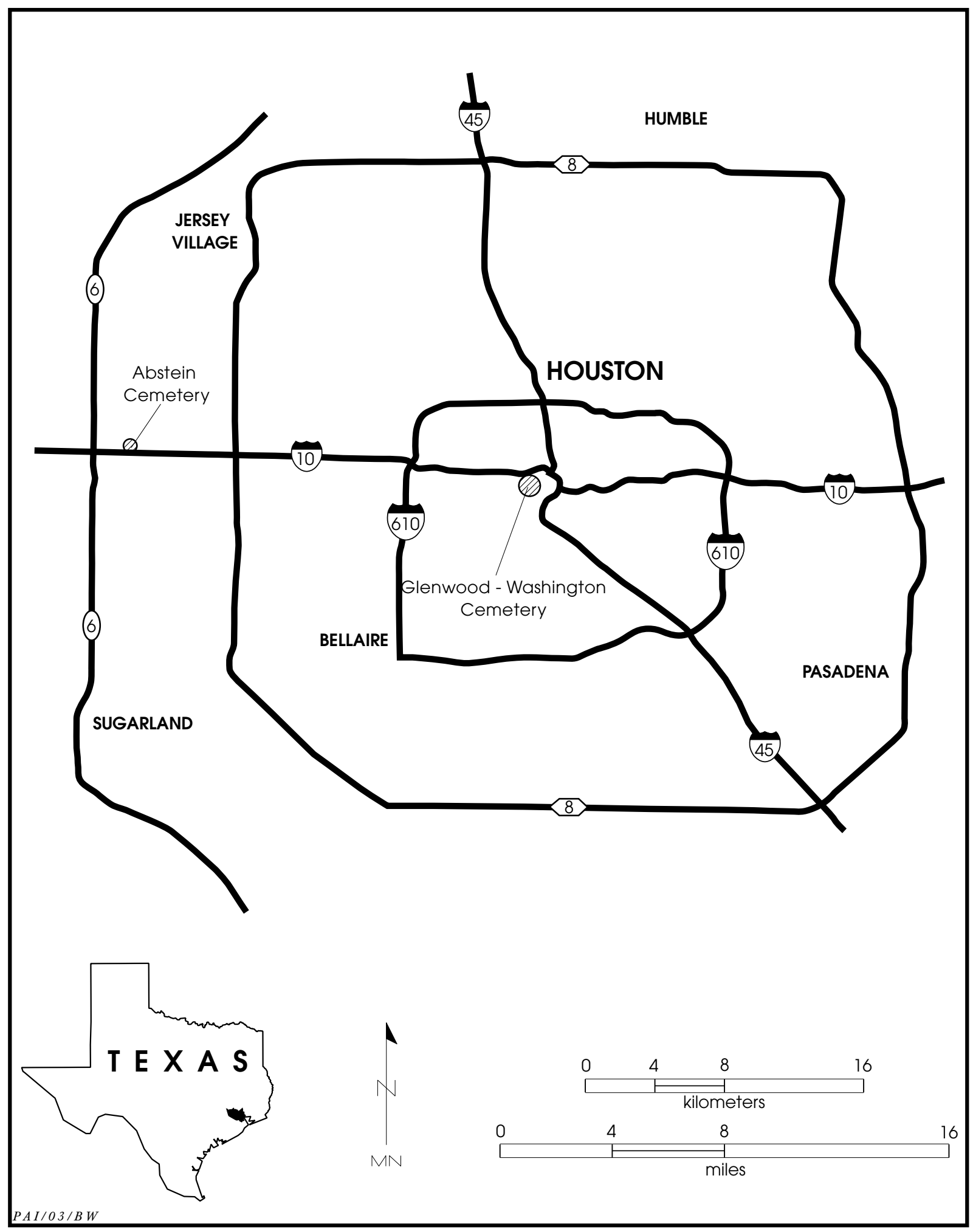

Figure 1. Project location map. 
County, Deed Record P:65), who sold 100 acres of Share 6 to H. Ludke (also spelled Lutge) on December 15,1854 . The acreage ran north from the north bank of Turkey Creek along the line that formed the boundary between the Wheaton and Hardin Surveys (present-day Eldridge Road) to the northeast corner of the Wheaton Survey, thence west to the west line of share 6 , thence south to Turkey Creek (Harris County, Deed Record P:511).

Ludke held the 100 acres until October 23, 1857, when he sold them to C. H. Schultze (Harris County, Deed Record T:333-334). Schultze then sold the 100 acres to Hy [sic] Golbow on June 28, 1871 (Harris County, Deed Record 9B:436), who conveyed the property to Henry Gastmann, together with two other tracts, on April 19, 1873 (Harris County, Deed Record 12:208).

Gastmann was born on November 26, 1826 (Harris County, Deed Record 79:200; 259:524). $\mathrm{He}$ and his wife Henrietta had three children: Anna (who married R. T. Eggling), Louis, and Mary (who married William Koehn) (Harris County, Deed Record 259:524). Henry and Henrietta owned the 100-acre tract on the east line of the Wheaton Survey on July 10, 1884, when a man named Oscar Abstein died. According to informants (Browning 2001; Koehn 2001), Abstein and a small child, "travelers," had stayed at a house in the area, and both of them had died after becoming ill. They were apparently buried on the Gastmann property, at what is now the northwest intersection of Eldridge Parkway and IH-10 but not in the Gastmann family cemetery. The Gastmann cemetery is north-northwest of the Abstein Cemetery and continued to be used until at least 1937. In 2002, headstones marked the burials of Henry Gastmann (November 26, 1826-December 15, 1896), Henrietta Gastmann (May 14, 1846-January 19, 1926), Louis Gastmann (August 26, 1872-September 15, 1937), and Maria Ohlendorf(September 15, 1837June 21, 1872).

On December 9, 1892, the Gastmanns deeded a 100-ft-wide right of way to the Missouri, Kansas and Texas Railway Company of Texas. The 100-ft-wide strip crossed over three different parcels of land owned by the Gastmanns, the first being in the William Hardin League east of present-day Eldridge Road, the second being on the east side of the Joel Wheaton League (Share 6) and location of the graves, and the third strip near the center of the Wheaton League. In the deed, the Gastmanns specified that "two graves, lying near the southerly limits of the second strip herein conveyed, shall remain undisturbed, and that the grave of Oscar Abstein on said same strip about twenty two feet from the center line of said railway shall be removed at the expense of said Railway Company" (Harris County, Deed Record 64:66-67) (Figure $3)$.

The Katy apparently moved Abstein's remains a short distance south and re-interred them closer to the two graves situated near the south line of the 100 -ft right of way sometime after December 1892. It is notable, however, that the 1892 deed record does not mention a child's grave.

As noted above, further information on the Abstein Cemetery was sought from Trevia Wooster Beverly, compiler of At Rest: A Historical Directory of Harris County, Texas[,], Cemeteries (1822-2001) (2001), and Howard Hicks, president of the Alief Cemetery Association. Mrs. Beverly had no record of the Abstein burial or of burials west of the Abstein burial on lots 3 and 4. Hicks also had no information about burials or cemeteries near IH-10 and Eldridge Parkway.

It is apparent that the cemetery was neglected for some time, and local citizens took steps to protect the cemetery in 1999. Charles Wm. Kruse, of the Alief Cemetery Associations and Alief Community Association, filed a "Declaration Of Dedication Of The: 'Oscar Abstein' and Presently 'Unknown Name Grave' Cemetery (Consisting of At Least These Two Known, Visible Graves)" with the Harris County Clerk's office. ${ }^{1}$ The document (photocopy on file with the Archeological Studies Program, Environmental Affairs Division, Texas Department of Transportation, Austin) was notarized on April 21, 1999, and filed on April 26, 1999. An attachment to the declaration document contains a map showing the cemetery location behind the "containment and retainment enclosure" and

\footnotetext{
${ }^{1}$ The Alief Cemetery is a historic cemetery situated at the southeast corner of Bellaire Boulevard and Dairy Ashford Road in Houston. The address for the Alief Cemetery Association and the Alief Community Association is 19102 Harlem Road, Richmond, Texas, 77469. The cemetery has a Texas State Historical Marker indicating it was associated with the community of Dairy, later renamed Alief.
} 
Chapter 1: Introduction

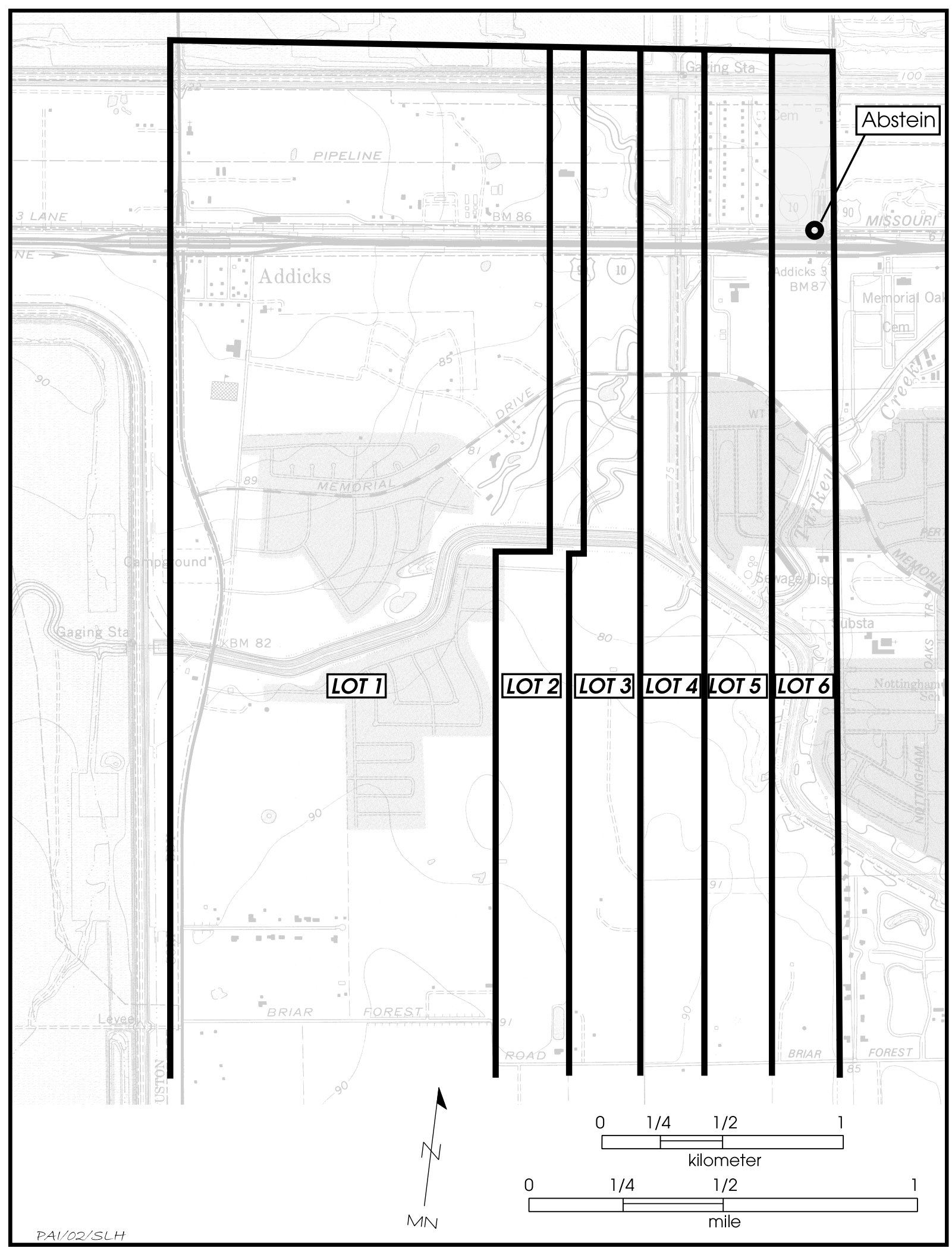

Figure 2. Location of Abstein Cemetery on Lot 6 of the subdivision of the Joel Wheaton Survey. 
Archeological Excavation and Reburial of Historic Graves, Abstein Cemetery

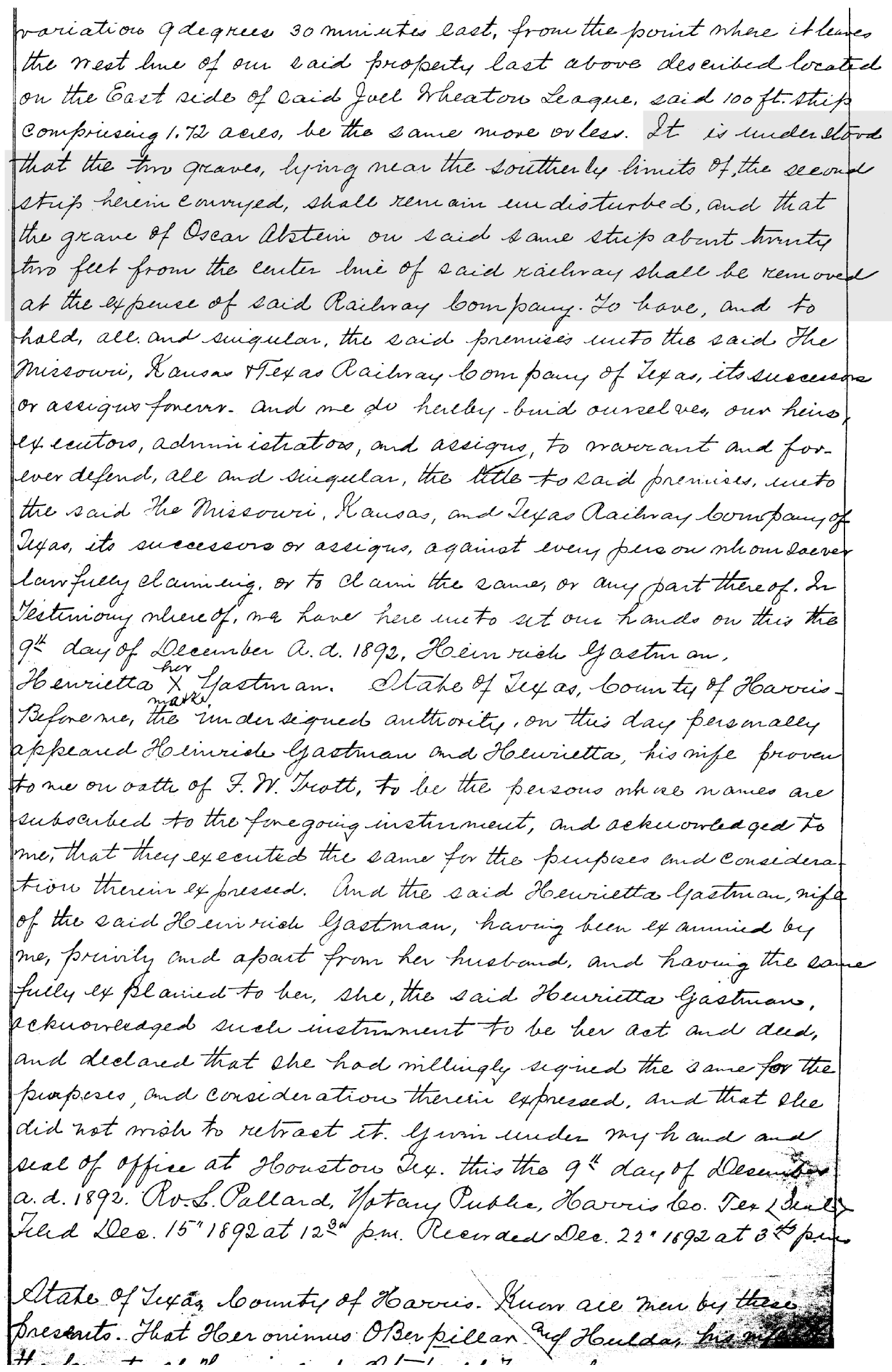

Figure 3. Deed record mentioning three graves in the Missouri, Kansas and Texas Railway Company right of way (Harris County, Deed Record 64:67). 
photographs of the headstones. This attachment states (unedited):

THIS PRESERVED AND RECOGNIZED HUMAN CEMETERY IS KNOWN TO BE ONE OF THE GERMAN ANCESTORY HISTORICAL CEMETERIES REMAINING RESIDING WITHIN THE PREDOMINATELY GERMAN-AMERICAN HISTORICAL TEXAS SETTLEMENT AREA OF BEAR CREEK, GROESCHKEVILLE, LETITIA, ADDICKS, HILLENDAHL AND SPRING BRANCH COLLECTIVE SETTLEMENT VICINITY.AND IN HISTORICAL RELATIONSHIP, THERE REMAINS RESIDING ANOTHER GERMAN HERITAGE HISTORICAL CEMETERY LOCATED WITHIN A FEW HUNDRED YARDS OF THIS PRESERVED HISTORICAL CEMETERY.

IT IS OBVIOUS BY SIGHT FROM THE STREET LEVEL (WHICH IS BELOW THE CEMETERY) THAT THE CEMETERY EARTH CONTAINMENT AND RETAINMENT ENCLOSURE WITH THE EXTENDED SUPPORTING CONCRETE ABUTMENT JOINING THE RIGHT OF WAY OF THE NORTH ELDRIDGE PARKWAY WESTBOUND INTERSTATE 10 FEEDER ROAD, WAS INTENTIONALLY CONSTRUCTED IN SUCH A MANNER TO PRESERVE THE CEMETERY. AND IT IS ALSO OBVIOUS THAT PRESERVATION WAS RIGHTFULLY ENACTED WHEN THE TWO HISTORICAL CEMETERY HEADSTONES WERE PREVIOUSLY AFFIXED INTO THE CEMETERY GROUNDS IN THE PRONE POSITION (FACE UP) WITH CONCRETE. UPON THE TWO SACRED CEMETERY GRAVESTHEMSELVES, THERE STILL REMAINS PREVIOUSLY PLANTED BULBOUS FLOWERING PLANTS. (THIS PRACTICE OF RESPECT FOR THE SACRED CONTINUES UNTIL THIS VERY DAY.) IN THE NAME OF JESUS, MAY GOD'S PEACE REMAIN WITH THIS CEMETERY. AMEN.

Charles Wm. Kruse

This document shows that the headstone fragments were already encased in concrete before April 1999. The two white wooden crosses erected on the site were placed there by Kruse sometime after the declaration was filed (Allen Bettis Jr., personal communication 2003).

In March 2002, TxDOT issued a supplemental work authorization to PAI to conduct additional archival research on Oscar Abstein. This work also was done by historian Martha Doty Freeman (2002). County records in Houston and Galveston-including deed, probate, naturalization, and oath of allegiance records-were reviewed. The historian also read issues of the Evening Journal (the only newspaper published in Houston during July 1884) at the Texas Room, Houston Public Library, and reviewed United States census records from 1850 to 1880 at the Clayton Library in Houston and the Texas State Library and Archives in Austin (U.S. Bureau of the Census). She reviewed listings in the Houston and Galveston City Directories at the Rosenberg Library in Galveston and the Texas Room. At the Texas State Library and Archives, she reviewed ad valorem tax records for Harris County from 1870 to 1884 and queried a computerized list of immigrants to Galveston that had been compiled by the Texas Seaport Museum in Galveston. She looked at all available volumes of Glazier and Filby's Germans to America: Lists of Passengers Arriving at U.S. Ports (1988-) at the Texas State Library and Archives and at Geue (1970) and Geue and Geue (1982). None of the sources reviewed mentioned or listed an individual named Oscar Abstein or any variant of that surname, such as Epstein.

\section{HISTORICAL FACTS}

The graves situated at the northwest corner of Eldridge Parkway and the westbound frontage road for IH-10 are on property that belonged to Henry and Henrietta Gastmann from April 19, 1873, until December 9, 1892. On or around July 10, 1884, Oscar Abstein and a small child died while traveling through the area and were buried on the Gastmann property, apparently near the location of two other graves. After the Gastmanns sold the property to the Katy Railway Company, the railroad was obligated to move the grave of Oscar Abstein and to leave the two other graves in the right of way undisturbed. Sometime after December 9, 1892, Abstein's burial apparently was moved a short 
distance to be closer to the two unnamed graves near the southern edge of the railroad right of way. Discrepancies were noted between various historic documents and maps, and it was unclear whether three or four graves existed at this location before the archeological search began. 


\section{METHODS AND RESULTS OF INVESTIGATION}

The goals of this project were to conduct a mechanical search to identify the three or four suspected graves, including the grave of Oscar Abstein; manually expose, document, and exhume the burial remains associated with each grave; conduct an onsite analysis of the human skeletal remains and associated cultural materials; and have the burial remains reinterred at a nearby cemetery.

\section{FIELD METHODS}

Before beginning the work at Abstein Cemetery, PAI archeologists prepared a scope of work and submitted an application for a Texas Antiquities Permit. Once the permit was obtained, prefield planning involved several crucial tasks. PAI contacted Richard Ambrus, the caretaker of Glenwood and Washington Cemeteries in Houston, who arranged for the reburial in the Washington Cemetery. ${ }^{1}$ TxDOT supplied a Gradall and operator. Because the project would involve mechanical excavations, PAI notified the OneCall Board of Texas, which responded that there were no buried utilities within the project area.

Field investigations at Abstein Cemetery included several different tasks accomplished over a 5-day period. The first day, mostly lost because of heavy rains, involved mainly a reconnaissance of the project area. The grave markers present on the surface were examined, and the amount of fill overlying the graves was discussed. The course of action necessary to ex-

\footnotetext{
${ }^{1}$ The Washington Cemetery adjoins the Glenwood Cemetery. Glenwood Cemetery, Inc., recently took over care of Washington Cemetery, and the two locations are sometimes referred to as the Glenwood-Washington Cemetery.
}

cavate mechanically to the depth of the graves in the limited area of the cemetery was also planned. The second day was devoted to locating the graves within the right of way. The third, fourth, and fifth days were devoted primarily to excavating three burials, field laboratory analysis of the human skeletal remains, and documentation of all material remains. The human remains and associated funerary materials from each burial were placed in reburial containers when excavation was completed and stored temporarily until the end of the project. On the fifth day, after all three burials had been excavated and analyzed, PAI archeologists took the reburial boxes containing all of the remains from the three exhumed graves to the Washington Cemetery for reburial.

After all three graves had been exposed, the cemetery area was mapped using a Sokkia Set $5 \mathrm{~F}$ total station to obtain accurate grave locations in relation to the concrete retaining wall and other features. After completion of the field work and the reburial, a site form was submitted to the Texas Historic Sites Atlas, and the Abstein Cemetery was designated 41HR976.

\section{RE-LOCATION OF UNMARKED GRAVES}

The first step in burial removal was to identify the locations of the graves within the IH-10 right of way. The only evidence of graves on the surface were two grave markers found inside the retaining wall. These broken headstone fragments had recently been set into two different concrete slabs about $3 \mathrm{~m}$ (10 ft) from one another and presumed to mark an eastern grave and a western grave. The eastern concrete slab encased six fragments fit together and set in con- 
crete to reconstruct most of the headstone. The western slab encased only two fragments. Both the eastern and western headstone fragments had inscriptions written in German. The eastern headstone fragments showed the name "Oscar Abstein" and the dates of his birth and death as 1846-1884 (Figure 4; see Chapter 3). Both of the concrete-encased clusters of headstone fragments were marked by vertical wooden crosses, with the larger cross designating the eastern grave being $2.9 \mathrm{~m}(10.5 \mathrm{ft})$ tall and easily visible from the westbound IH-10 frontage road. The western cross was constructed in the same manner but was only $71 \mathrm{~cm}$ (28 in) tall.

It was suspected that these headstones marked the actual locations of graves, but they were obviously not in their original positions because the stones had been laid in concrete sometime before 1999. It was also clear from the historic maps and documents that these markers were on top of an unknown amount of fill brought in when the concrete retaining wall was built around 1965 (Figure 5). Furthermore, it was later established that the two headstone

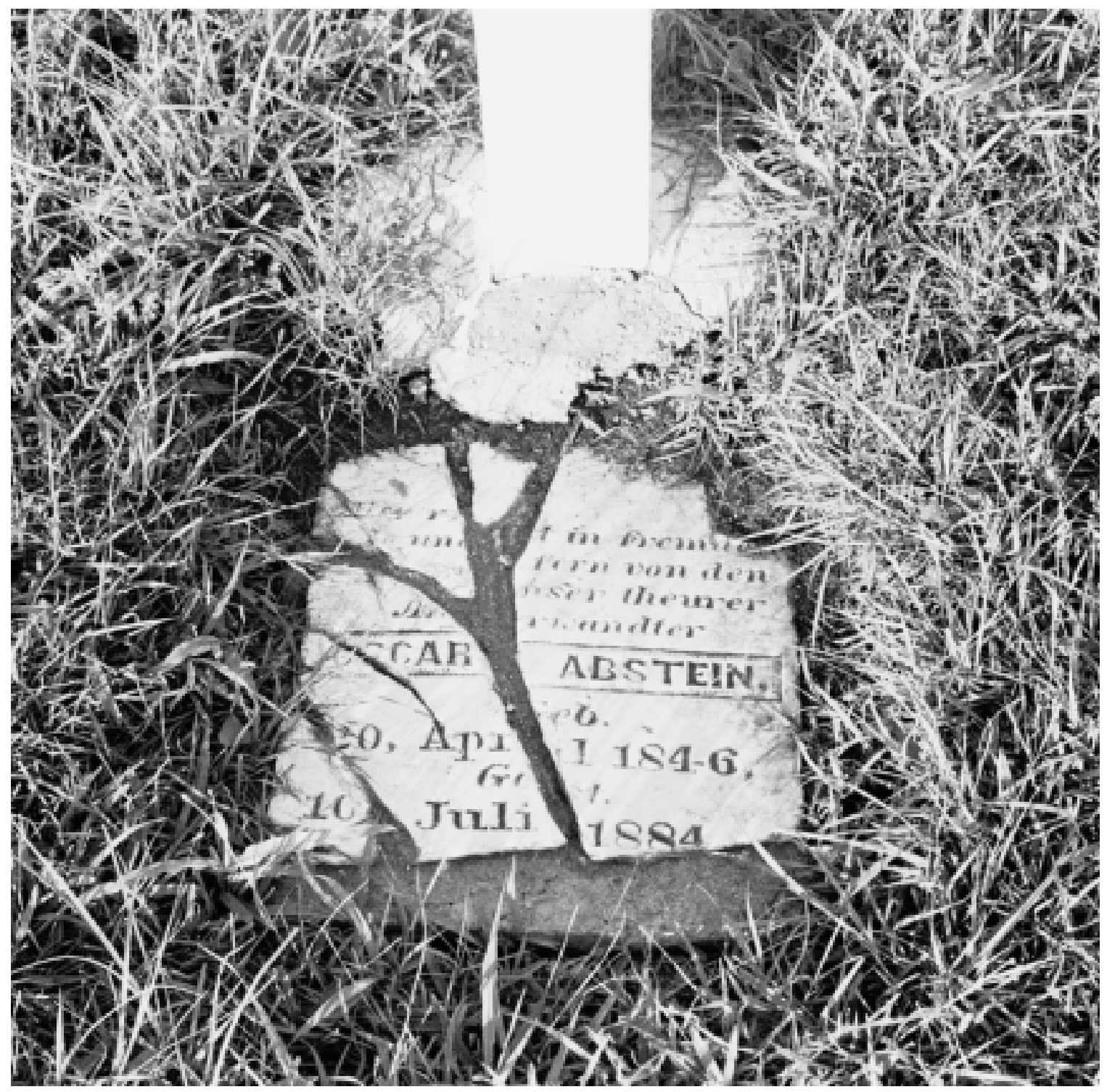

Figure 4. Photograph of eastern grave marker at Abstein Cemetery. The base of the white wooden cross is at the top of the photo, above the concrete-encased fragments of Oscar Abstein's headstone. He was born on April 20, 1846, and died July 10, 1884, at the age of 38. These headstone fragments were set into two different concrete slabs sometime before 1999 . 


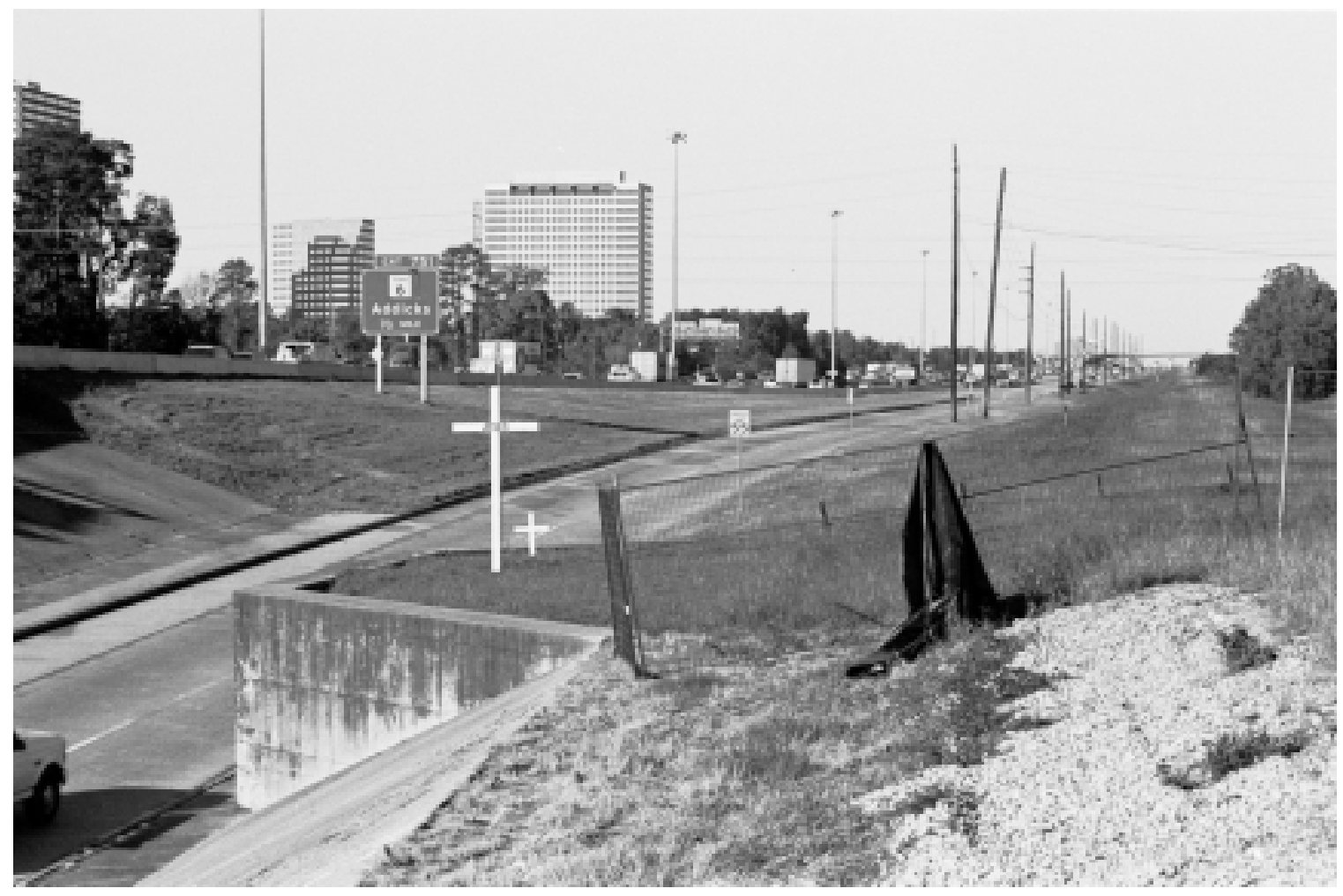

Figure 5. Photograph of Abstein Cemetery before the archeological excavations began, looking west. The two white crosses mark the suspected grave locations protected by the concrete retaining wall. The Interstate Highway 10 westbound access road is at the bottom left, and the interstate is above and behind the access road.

fragments cemented together to form the western grave marker were actually the bottom pieces of Abstein's headstone, which had been cemented together as the eastern grave marker. This discovery meant that instead of two grave markers, there was actually only one.

Further information on the locations of the graves came from TxDOT schematic construction maps from three different road construction episodes (Texas State Highway Department 1931, 1954, and 1965). A 1931 map showed locations of four graves but provided no information indicating what surface evidence differentiated these grave locations. But a 1954 map showed only two graves, and a later 1965 map showed two grave locations, as well as the detailed plans for a concrete retaining wall that was to be built to protect them (Figure 6). The plans precisely match the concrete retaining wall that is there today. When the 1931, 1954, and 1965 Texas State Highway Department maps were reviewed along with the oral history evidence (about Oscar Abstein and the child) and the 1892 deed record (referring to Abstein's grave and two other unidentified graves), it was clear that at least three graves were likely to be present, but it was uncertain whether the fourth grave really existed.

The 1965 map and plan of retaining wall details were used as the guide for the initial placement of the mechanical trenches. The two graves shown on the retaining wall plan map would have been the easternmost of the possible four graves shown on the 1931 map. All three maps showed these graves were close to, and north-south of, one another. A Gradall was used to conduct the subsurface search, and a large area behind the retaining wall was cleared. The trenching ultimately led to discovery of two buried plinths (headstone bases) and the identification of three grave shafts designated as Burials 1, 2, and 3 (Figures 7 and 8).

The initial Gradall trench was excavated north-south across the area where the easternmost burials were suspected. Burial 1, the more northern of the two graves, was quickly identified, based on the looser, more irregular consistency of its grave shaft fill and its grayer color. Once discovered with the Gradall, the grave shaft of this burial was gradually scraped in thin 2-5$\mathrm{cm}$ (1-2-in) layers with the Gradall until wood 


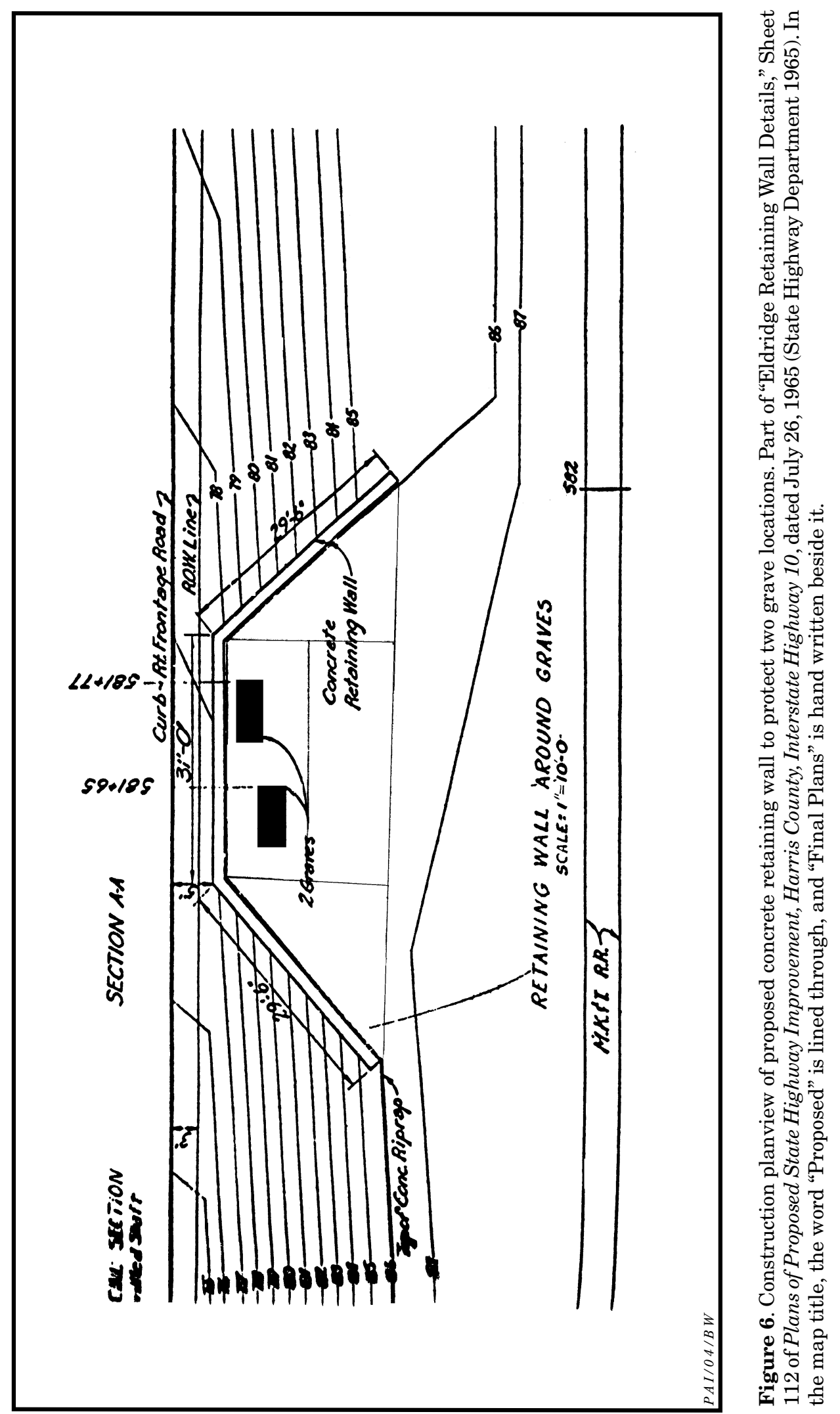




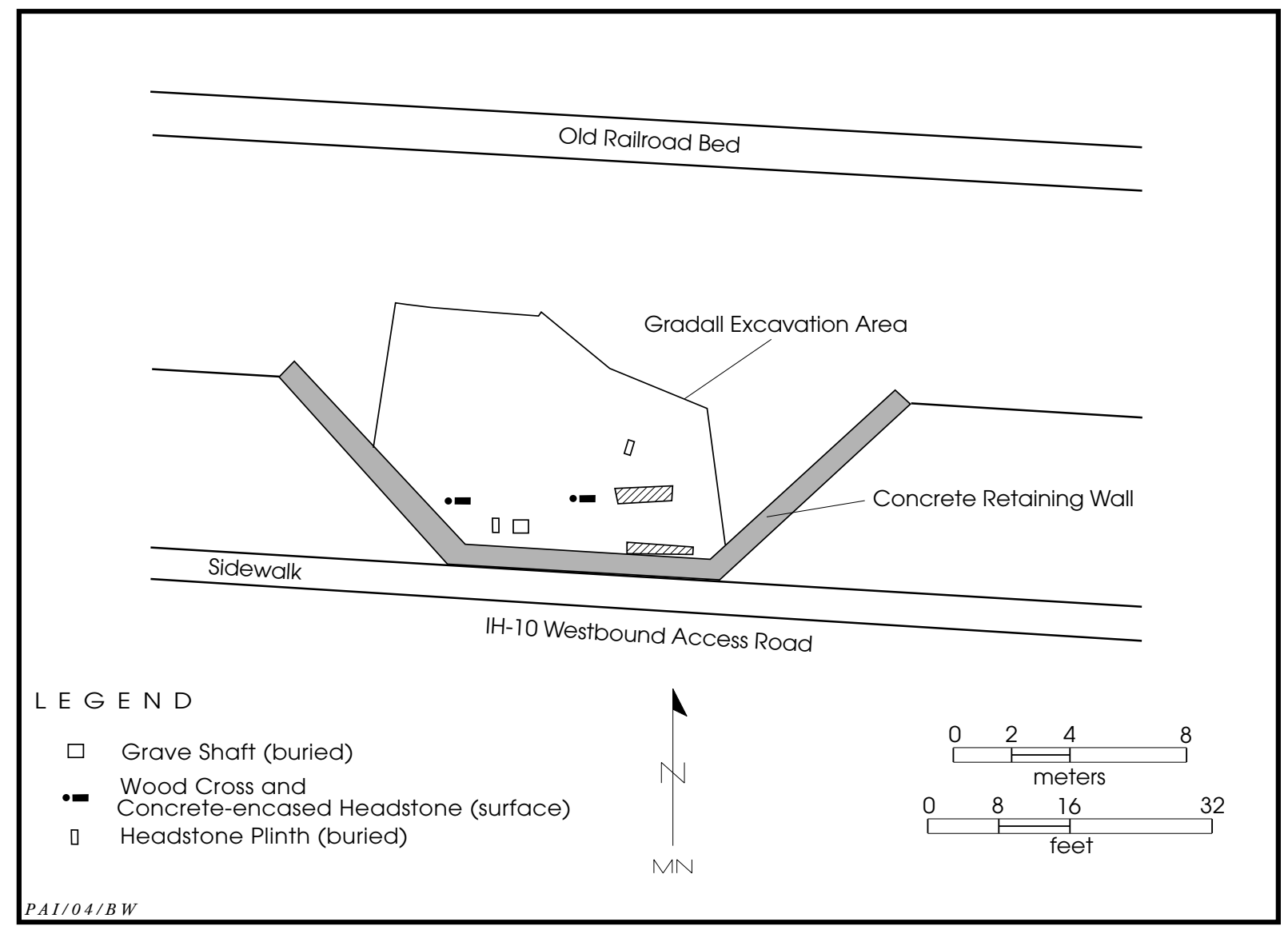

Figure 7. Planview of grave markers on surface and buried plinths found during trenching.

from the burial container was encountered. After the overburden had been removed from the grave, mechanical activities ceased, and exposure of the burial proceeded by hand.

More trenches were then excavated to the west and the east of the original trench to expose Burial 1 completely, search for the suspected grave to the south of it, and seek out additional graves shown to the west on the 1931 map. During these excavations, a plinth was found near the head of Burial 1. Its base was about $70 \mathrm{~cm}$ (27.5 inches) below the top of the retaining wall. The suspected grave south of Burial 1 could not initially be identified, and it was felt that the construction of the retaining wall might have destroyed it.

Further study of the maps suggested at least some portion of this grave might still remain right up against the retaining wall. Careful scraping south of Burial 1 and immediately adjoining the retaining wall did indeed expose another shaft, designated Burial 2. An attempt to scrape the overburden from this grave mechanically was unsuccessful. Because the grave was so close to the retaining wall, the Gradall could not easily remove the overlying sediment. A vertical cut destroyed the northernmost edge of the burial, and mechanical excavation was then halted. Fill from this area was screened to recover the burial remains, and the overburden above Burial 2 was then removed by hand excavation.

Gradall trenching to the west of Burials 1 and 2 revealed another plinth at $48 \mathrm{~cm}$ (19 in) below the top of the wall. Because a buried plinth had marked the approximate location of Burial 1 , mechanical excavation proceeded with extra care under this plinth. At about $107 \mathrm{~cm}$ (42 in) below the top of the wall and under the second plinth, the Gradall exposed a cluster of bones near the interface of the original (pre-1965 fill) ground surface and the underlying Beaumont Formation. These remains were designated Burial 3. The shaft of this burial was almost impossible to see because it was partially in the construction-truncated A horizon and penetrated minimally into the Beaumont clay, where the shafts of Burial 1 and 2 were easily visible. 


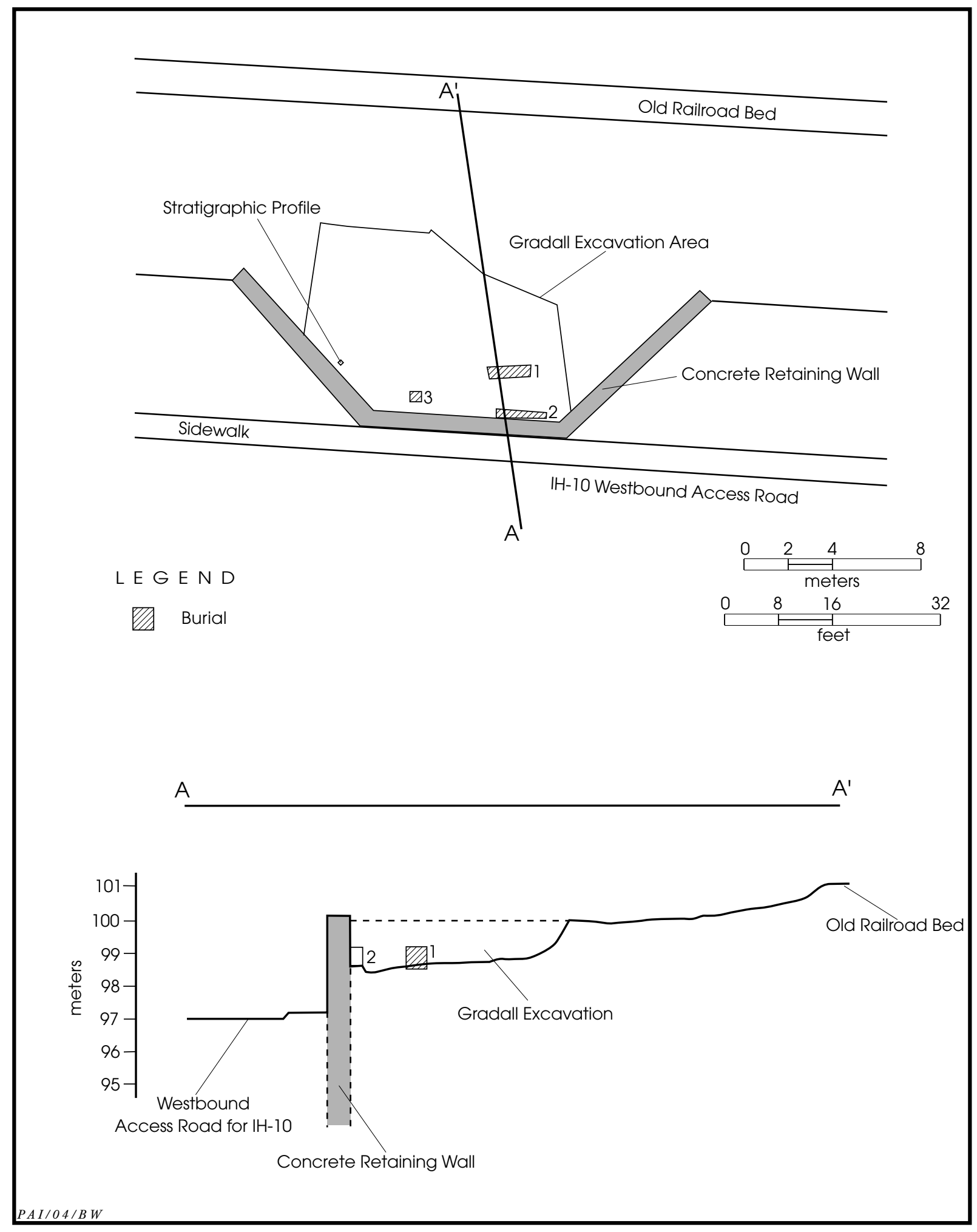

Figure 8. Planview and profile of re-located grave shafts in the Abstein Cemetery. The concrete retaining wall was built by the State Highway Department about 1965 to enclose and protect the graves. 
Because the 1931 map showed a fourth grave, Gradall scraping continued to the north and west of Burial 3 and down through the Beaumont clay until PAI archeologists felt that if a grave or graves were present, it would be visible. No other graves were found, however.

At the conclusion of the Gradall search, a large, irregularly shaped block that measured ca. $12 \mathrm{~m}$ east-west by $8 \mathrm{~m}$ north-south was excavated behind the retaining wall and down 1 to $1.5 \mathrm{~m}$ deep into the Beaumont Formation clays. This large open block also allowed enough space for the excavators to work safely and for a tent to be set up for analysis of human remains and associated artifacts (Figure 9).

Generally, once each grave shaft outline was defined, two field crew members excavated the grave with small hand tools (primarily trowels, brushes, and bamboo skewers). Because it was so small, a single excavator was assigned to Burial 3.

Once each burial was exposed, the grave shaft, burial container(s), individual skeletal elements, mortuary hardware, and personal effects were drawn in planview. The bones of the skeleton were bagged and labeled individually. Mortuary hardware and personal effects were collected and labeled based on which of five separate zones of the skeleton they came from: cranial; left, above iliac crest of the pelvis; right, above iliac crest; left, below iliac crest; right, below iliac crest (after Guendling et al. 1985).

To ensure that as many bone and funerary objects were recovered as possible, coffin fill immediately surrounding the skeletal remains in each burial was screened through a $1 / 4$-inch mesh screen.

Skeletal preservation ranged from poor to good, as defined in Buikstra and Ubelaker (1994). The bones in Burial 1 were fairly well preserved, those in Burial 2 were less well preserved, and those in Burial 3 were poorly preserved. Many of the bones and bone fragments in Burial 2 and especially in Burial 3 were in such poor condition that identification and meaningful analysis of both Burials 2 and 3 were largely impossible.

Each excavation team filled out a 7-page burial excavation form for each burial (see Tiné and Boyd 2003:Appendix B). Information collected included soil color and consistency; burial

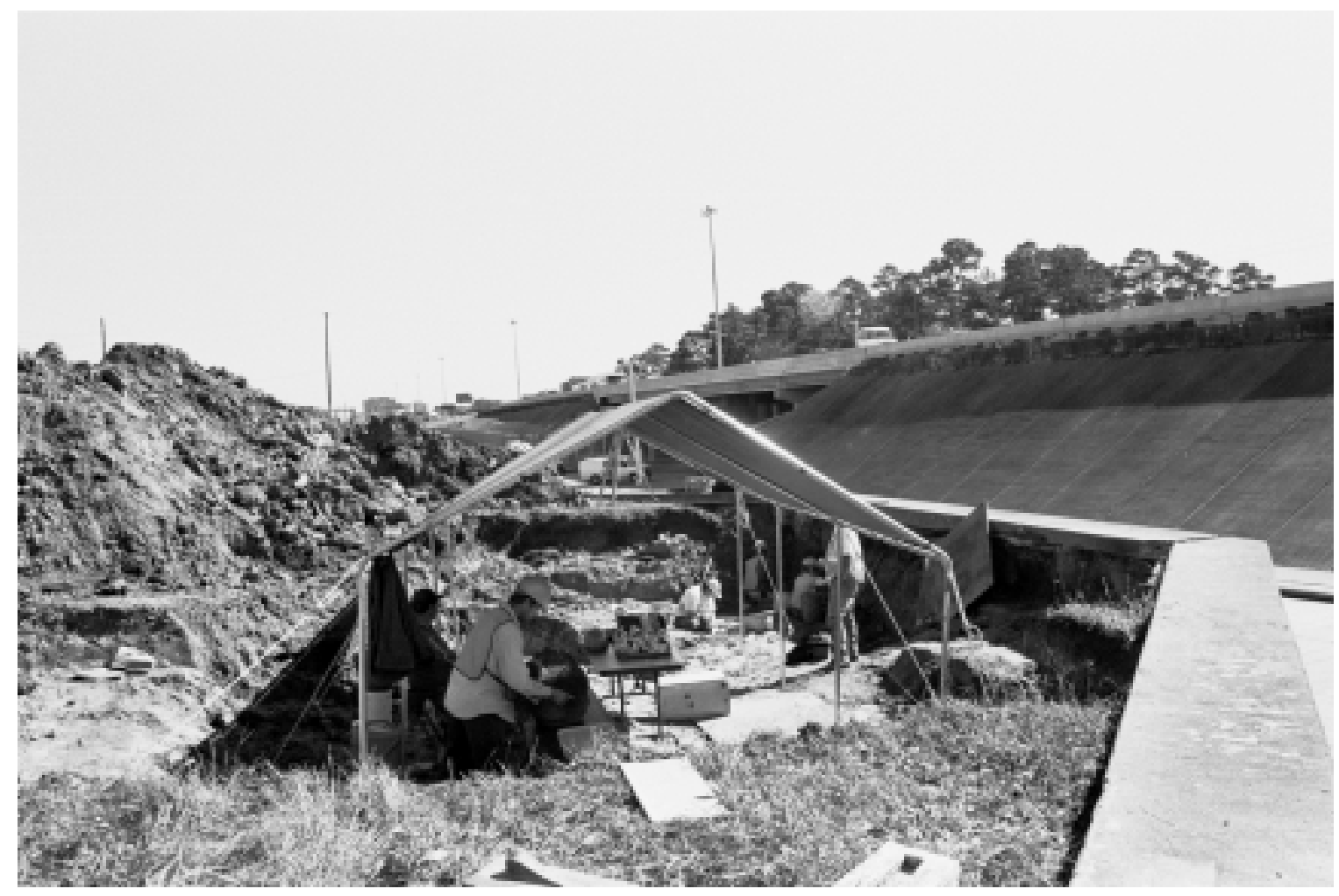

Figure 9. Photograph of excavation block at the Abstein Cemetery, looking east with Interstate Highway 10 in the background. The large tent served as the field laboratory. The excavators behind the tent are working on Burials 1 and 2, the latter immediately adjoining the concrete retaining wall. 
orientation; depth of the burial container below the retaining wall; dimensions of the burial container; container shape and material; presence and location of associated artifacts; condition and position of the skeletal remains; and any other noteworthy features (e.g., color of burial container). A scaled diagram of each burial was drawn to show the spatial relationships between the burial container, the skeleton, and associated artifacts. Excavators also made notes on any disturbances that were observed. Field documentation of the graves involved black-and-white print and color slide photographs of the fully exposed skeleton and burial container.

Because of the sensitive nature of the project and public setting, as well as safety concerns, the burial excavation area was barricaded so people could not get close to the graves. The excavations were scheduled so that remains were left exposed for as short a time as possible. When the disinterment of each burial was completed, the remains and associated materials were removed from the grave by hand and transferred to a wooden reburial container, and each box was discretely labeled with the burial number. The reburial boxes that TxDOT provided were made of pine wood, and each one measured $2 \mathrm{ft}$ long, $1 \mathrm{ft}$ wide, and $1 \mathrm{ft}$ tall. After the three burials were removed, the Gradall was used to backfill the excavations.

\section{ARCHEOLOGICAL AND BIOARCHEOLOGICAL EXAMINATIONS}

The project scope required that the remains and artifacts be reburied, preferably in a perpetual care cemetery, immediately after excavation and analysis. After they were removed, the human bones and associated material remains from each grave were processed and analyzed in an on-site laboratory that consisted of a tent and two large work tables. When necessary, bones and artifacts were washed with water and then dried thoroughly. Analysis included osteological examination of the human remains, analysis of the funerary hardware and other grave inclusions, and photographic recordation of the human remains and artifacts.

\section{Osteological Analysis}

The osteological coding system used for this project was adapted from Standards for Data Collection from Human Skeletal Remains (Buikstra and Ubelaker 1994). The 12-page form used was the same one used for the Texas State Cemetery in Austin, another historic burial recovery project that PAI archeologists (Dockall, Boyd, et al. 1996:Appendix C) completed. The initial osteological analysis of each skeleton recovered at Abstein Cemetery entailed an inventory of skeletal elements present. The inventory was recorded using a numerical code that indicated both the completeness of each bone and its overall condition. Where possible, observations on sex, age, pathological conditions, and nonmetric traits of the skeleton were recorded on a standardized form. Standard measurements of specific skeletal elements were also taken when possible. All inventories and observations were supplemented by handwritten notes when applicable.

Biological affinity based on the skeleton could not be assessed for any of the burials because of the relative lack of indicators (see Gill and Rhine 1990). Nor were nonmetric traits of the cranium and postcranial skeleton-which follow the guidelines of Buikstra and Ubelaker (1994) defining nonmetric traits of primary importance and the procedures for scoring them-observable because the remains were in poor condition and incomplete. In general, the overall poor condition of the remains precluded most types of analyses on Burials 2 and 3, but limited analyses were possible for Burial 1.

Sex assessment of adult remains was determined on the basis of cranial and pelvic morphology as defined and illustrated in Buikstra and Ubelaker (1994), based on Ascádi and Nemeskéri (1970:Figure 16) and supplemented by an assessment of the overall robusticity of the skeletons. Scores were assigned to sexually dimorphic traits based on a gradient ranging from female to male. No attempt was made to sex subadult remains because the skeletons of such young individuals lack reliably sexually dimorphic features.

Age estimation for Burial 1 was based on dental wear (Brothwell 1981:p. 72, Figure 3.9; Miles 1958, 1962), cranial suture closure (Mann et al. 1987, 1991; Meindl and Lovejoy 1985), and severity of articular surface changes. Data allowing more specific age estimation (e.g., pubic symphysis or auricular surface morphology) were not available. In Burials 2 and 3, age esti- 
mation could only be based on the size and robusticity of the bones, with limited epiphyses also observed on Burial 2, and these burials could be assigned only to broad age categories such as adult and child.

Standards for recording pathological conditions of the skeleton were documented using numerical codes based primarily on the type of pathology and its severity, extent, and etiology (Buikstra and Ubelaker 1994), as well as with handwritten notes. The types of measurements taken followed the list of standard linear measurements defined in Buikstra and Ubelaker (1994). These measurements were taken with a pair of digital sliding calipers or cloth tape.

Dental data were also collected through macroscopic observations according to Buikstra and Ubelaker's (1994) guidelines. Occlusal wear scoring is based on Smith (1984; after Murphy $1959 \mathrm{a}$; 1959b) for incisors, canines, and premolars and Scott (1979) for molars. The dental inventory included a tabulation of teeth present, an assessment of pre- versus postmortem tooth loss, and the extent of development and eruption. Further potential data to collect included location and degree of calculus deposits; presence and location of all observable caries and abscesses; premortem damage (such as chipping) or modification, degree of attrition; and the presence of enamel hypoplasias. Where necessary, characters of the dentition were described with additional handwritten notes to supplement the inventory sheets. Where possible, identification of nonmetric traits of the dentition followed the descriptions and scoring set forth by Turner et al. (1991; see also Scott and Turner 1997). No dental measurements were taken.

All pathological or anomalous conditions observed on skeletal elements and dentition, as well as skeletal attributes suggestive of age or sex, were photographed using color slide film.

\section{Artifact Analysis}

All artifacts found in association with burial remains were examined and documented on a standardized Artifact Identification Form (see Tiné and Boyd 2003:Appendix B). Data on artifact type, material, dimensions (measured with metric digital sliding calipers), manufacture style, and location within the grave were recorded. Each artifact was documented through sketches, notes, and photographs. For analysis purposes, artifacts are grouped as mortuary items (like coffin hardware) or personal belongings.

\section{PUBLIC INVOLVEMENT AND REBURIAL}

Despite its high visibility off a busy interstate highway in a major metropolitan area, the project invoked little interest from the general public. Visitors to the site were primarily personnel from TxDOT and Parsons, Brinkerhoff, Quade, and Douglas, Inc., the engineering firm overseeing the IH-10 upgrade. The lack of interest from the larger community suggests a lack of connection between the cemetery, as a social entity in its own right, and the greater surrounding community as well as a lack of connection between the individuals interred there and the greater community.

The cemetery contains a small number of graves and only one individual of known identity, and even Oscar Abstein was apparently a stranger in the area when he died. Thus, there are no local familial relations to memorialize their final resting place, and knowledge about the people interred in these graves was lost in the past century. Likewise, local cemetery associations, often the extended caretakers for these types of cemeteries, had little information on these graves.

Because the exhumed remains could not be re-interred in another spot within the Abstein Cemetery itself, TxDOT authorized PAI to investigate suitable locations for their re-interment. Suitability depended primarily on physical location in relation to the present cemetery, acceptance of re-interments, availability of space, perpetual maintenance, affordability, religious association, and ethnic affiliations. Religious association and ethnic affiliation rested on the assumption of a German ethnic background for Oscar Abstein, although his origin is in reality not certain, and the ethnic derivation of the other people exhumed is entirely unknown.

Freeman (2002) investigated four nearby cemeteries as possible reburial locations. The Addicks-Bear Creek Cemetery in the Addicks area is a Methodist cemetery and is physically closest to Abstein Cemetery. The Alief Cemetery in Alief dates to the late nineteenth and early twentieth centuries and contains primarily Anglo-American burials. The Glenwood Cem- 
etery, a well-known cemetery near downtown Houston, is very well maintained and known for its prominent historic burials.

The Washington Cemetery, adjoining Glenwood Cemetery and formerly known as the Deutchse Gesellschaft von Houston, was founded for the local German population. Also known as the Epstein Cemetery, the Washington Cemetery dates to the late nineteenth century, approximately the same period as the burials at the Abstein Cemetery. Although the cemetery has no religious affiliation, many burials there are associated with the Lutheran denomination, and there have been several reinterments there.

After Freeman (2002:19) studied possible reburial sites (2002:19), TxDOT determined that the Washington Cemetery was the most suitable for re-interment of the burials from Abstein
Cemetery because of its known German affiliation, its burials associated with the Lutheran denomination, and its use for several re-interments. It also is well maintained and is relatively inexpensive.

\section{CURATION OF MATERIALS}

After analysis and documentation, all human remains and associated artifacts were re-interred at Washington Cemetery in Houston. All field and laboratory records and maps were prepared for curation and placed in archival-quality containers. Field notes, burial forms, photographs, and other data gathered during these investigations will be curated, at least temporarily, at the Archeological Studies Program offices of the Environmental Division, Texas Department of Transportation, in Austin, Texas. 


\section{BURIAL DESCRIPTIONS AND ANALYSIS}

This chapter describes each of the three excavated graves. Burials 1 and 2 each contained remains of a single person, and Burial 3 contained the remains of two individuals. Data for the excavated burials consist of details about burial depth, orientation, and body position; an inventory of coffin hardware and artifacts associated with the burial; an osteological inventory; demographic and pathological information; a dental inventory; and descriptions of dental pathology, anomalies, and modifications. A glossary of technical terms is provided as Appendix A, and skeletal inventories and observations for all three burials are presented in Appendix B.

In the following descriptions, burial depth refers to the distance from the top of the concrete retaining wall across the southern end of the cemetery to the bottom of the burial container, as calculated based on total station mapping data. This wall is approximately 15 to $20 \mathrm{~cm}$ above the existing ground surface, which was artificially raised above the level of the original ground surface at the time the burials were interred. The original ground surface is approximately 85 to $95 \mathrm{~cm}$ below the top of the concrete retaining wall. According to the State Highway Department's 1965 construction plan entitled "Eldridge Retaining Wall Details," the top of the retaining wall is at approximately $86 \mathrm{ft}$ above sea level.

\section{BURIAL 1}

Burial 1 is interpreted as the grave of 30 - to 40-year-old female whose identity is unknown.

\section{Mortuary Characteristics}

Grave Marker: No grave marker is definitely associated with this burial. Before the excavation began, a prominent marker was located about $1 \mathrm{~m}$ west of the head of where Burial 1 was found (see Figure 6). The marker was a large white wooden cross $(290 \mathrm{~cm}$ tall by $137 \mathrm{~cm}$ wide and made of $4 \times 4$ in posts) set in concrete in the ground and beside the fragments of Oscar Abstein's headstone, the latter being cemented together and lying flat in a slab of concrete. It was later concluded that Burial 1 did not contain the remains of Oscar Abstein and that these pieces of the headstone had been displaced.

A limestone plinth (grave marker base) was found about $1.5 \mathrm{~m}$ north of Burial 1 and buried at about $70 \mathrm{~cm}$ below the top of the retaining wall. The plinth was neatly cut limestone and measured $19.1 \mathrm{~cm}$ tall, $21.6 \mathrm{~cm}$ wide, and $45.7 \mathrm{~cm}$ long ( $7.5 \times 8.5 \times 18.0$ inches). The top of the plinth still had a broken fragment of a soft white marble headstone inside the $25.4-\mathrm{cm}$-long by $5.1-\mathrm{cm}$-wide (10x2 inches) slot. The broken edges of the headstone base were not fresh, and it is presumed that the headstone was broken and disappeared long ago. Because it is near the grave, this plinth may have been associated with Burial 1 .

During the Gradall search, four probable postholes were observed in vertical profiles near Burial 1. One was about $80 \mathrm{~cm}$ south of the head (west) end of Burial 1. The other three postholes formed a north-south line, with the southern posthole about $80 \mathrm{~cm}$ west of the head end of Burial 1. These posts were about 80 to $90 \mathrm{~cm}$ apart. It is not known what these holes represent, but they could be from a small fence that once enclosed Burial 1.

Burial Shaft Size and Depth: The grave shaft measured $197 \times 61 \mathrm{~cm}$ (77.6x24.0 inches). The bottom of the grave shaft was $157 \mathrm{~cm}$ (62 inches) below the concrete retaining wall. 
Coffin / Casket Description: The coffin was a wooden, 6-sided hexagonal burial container with the sides tapered toward the feet and, to a lesser extent, the head. It measured $189 \mathrm{~cm}$ (74.4 inches) long and ranged from $24 \mathrm{~cm}$ (9.5 inches) wide at the head to $32 \mathrm{~cm}$ (12.6 inches) wide at the shoulder to $14 \mathrm{~cm}$ (5.5 inches) wide at the foot. The coffin was placed in the grave shaft inside a wooden rectangular outer box that measured $191 \mathrm{~cm}$ (75.2 inches) long and at least $32 \mathrm{~cm}$ (12.6 inches) wide. The type of wood used in construction of both the coffin and outer box could not be identified because it was extremely deteriorated.

Coffin / Casket Hardware: No coffin hardware was associated with Burial 1. The clayey subsoil beneath the coffin in the thoracic region showed a greenish tint and may represent the last remnant of an oxidized metal piece of hardware (possibly brass) that was part of the coffin or outer box. It is presumed that some type of iron nails were used in constructing the coffin and outer box but that these had deteriorated to the point of being unrecognizable.

Body Orientation: East-west; head to west.

Body Position: The body was buried in an extended, supine position. The left hand rested on the left os coxae, and the right hand, on the right os coxae.

Personal Items: Two oval antler or bone, twohole buttons were recovered just left of the midline of the upper torso (Figure 10). The buttons are identical. The fronts of the buttons are flat, and the backs, convex. The fronts show only one large hole that would encompass the area of the two holes on the reverse. The front of each button is beveled along its margin. The backs of the buttons show two small holes framed by a shallow round concavity. A groove is present on each button, continuous along the edge. Each button is $20.5 \mathrm{~mm}$ long, $13.5 \mathrm{~mm}$ wide, and $4.7 \mathrm{~mm}$ thick.

\section{Osteological Characteristics}

Preservation / Taphonomy: Overall skeletal preservation typically ranged from fair to good, with some elements poorly preserved. The long bones of the arms and legs were in the best state of preservation. Fragmentation was common but did not hinder analysis. Articular surfaces were commonly present and analyzable. The cranium
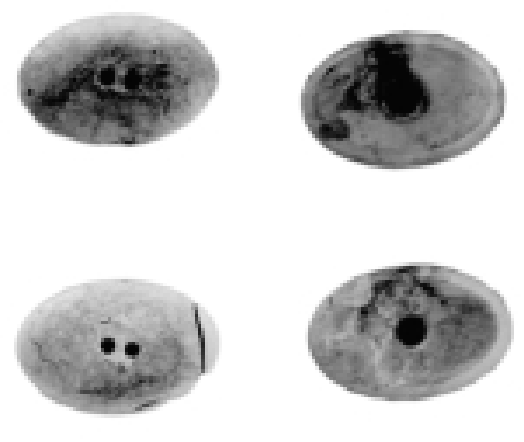

Top View

Bottom View

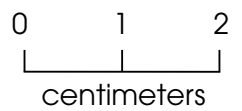

Figure 10. Bone buttons from Burial 1.

was crushed. Several maxillary and mandibular molars show gray discoloration that does not appear to be pathological in origin. The maxillary left first molar shows signs of in situ deterioration. The bones of the feet had disarticulated and shifted within the burial container to a minor extent.

Sex: Female. Overall skeletal robusticity is relatively gracile, and muscle insertions and origins are not well marked. The robusticity of the exterior occipital protuberance and mastoid processes, the shape of the mental eminence, the degree of gonial eversion of the mandible, and the shape of the greater sciatic notch of the ilium are all markedly female in morphology.

Age: Estimated age is approximately 30 to 40 years based on dental wear (Brothwell 1981:72, Figure 3.9; Miles 1958; 1962) and limited observations of cranial sutures. The only ectocranial suture visible is at midlambdoid and shows between minimal and significant closure (Meindl and Lovejoy 1985:58). In the palate, the incisive suture appears to be completely closed and obliterated. Although it is not recommended that age estimation based on cranial sutures be based on one observation alone, the observation at midlambdoid suggests an age of approximately 43 years, with a standard deviation of about 11 years (Meindl and Lovejoy 1985:61 Table 3). The incisive suture is obliterated at the earliest at 20 to 25 years but more commonly after 30 years (Mann et al. 1987; 1991).

Skeletal Inventory: The skeletal remains consist of the frontal; left and right parietals; left and right zygomatics; the occipital; the man- 
dible; the left and right humeri, radii, and ulnae; the left and right femora, tibiae, and fibulae; left and right clavicles; fragments of the left and right scapulae; the left and right second ribs; at least seven ribs (numbers 3-10) on the left and right side each; a right rib 11 or 12 ; left scaphoid and capitate; three unsided metacarpal shafts; four left manual phalanges ( 2 proximal, 1 distal, 1 indeterminate); fragments of the neural arches of five thoracic vertebrae and one lumbar vertebra; the left and right ilia; the right ischium; the right patella; the left calcaneus, navicular, and the first, second and third cuneiforms; the right talus, navicular, and first, second, and third cuneiforms; the left and right metatarsals I to V; and four unsided pedal phalanges.

Dental Inventory: Maxillary: all teeth present except the right central incisor and the left lateral incisor. Mandibular: all teeth present except the left central incisor and the right central and lateral incisors.

Skeletal Nonmetrics: None observed.

Dental Nonmetrics: The maxillary incisors are shovel shaped. The maxillary left and right first molars and the maxillary right second molar show well-developed hypocones. The mandibular left first molar exhibit a hypoconulid. The mandibular left and right second molars show a Y groove pattern.

\section{Skeletal Pathology}

Degenerative: The margins of almost every joint surface present show extremely slight osteophytic lipping. The thoracic and lumbar vertebral zygapophyses show slightly more severe involvement than other joints of the skeleton.

Traumatic: None observed.

Infectious: None observed.

Neoplasm: None observed.

Metabolic and Hematological: None observed.

Other: None observed.

Dental Pathology: Although several anterior teeth were missing, there was no evidence they were lost ante-mortem. The alveolar bone of the anterior dentition shows deterioration that was taphonomic in origin, and this may have obscured any signs of alveolar bone loss associated with ante-mortem tooth loss. The maxillary left third molar and both mandibular third molars are impacted. The mandibular right first molar shows contiguous loss of the crown and discol- oration on its occlusal and mesial surfaces consistent with a carious lesion. However, the extent crown edges are angular and sharply defined. Further, the crown of the second premolar has intruded partially into the possible lesion but shows no evidence of cariogenesis itself.

Other: The mandibular canines are rotated laterally.

\section{BURIAL 2}

Burial 2 is interpreted as the grave of an adult of indeterminate sex whose identity is unknown.

\section{Mortuary Characteristics}

Grave Marker: No grave marker was found in close proximity to Burial 2 (see Figure 6), and it is presumed that any marker that may have been present either was perishable (e.g., wooden) and deteriorated or was moved or destroyed long ago.

Burial Shaft Size and Depth: The grave shaft was estimated to measure at least $190 \times 45 \mathrm{~cm}$ (74.89x17.72 inches). Both measurements of the grave shaft could not be exactly determined because the northeast corner was truncated during Gradall excavation. The bottom of the grave shaft was $153 \mathrm{~cm}$ (60 inches) below the top of the retaining wall.

Coffin / Casket Description: The type of burial container present could not be determined because it was poorly preserved and partially damaged by the Gradall. It appears, however, to have been a rectangular or tapered casket that had straight sides. It measured at least $190 \mathrm{~cm}$ (74.89 inches) long and up to $45 \mathrm{~cm}$ (17.72 inches) wide. It was manufactured from wood, although its condition was too poor for identification.

Coffin / Casket Hardware: Five machine-cut square nails and nail fragments were associated with the burial container, but these were heavily corroded iron. There were probably other iron nails present but too deteriorated to detect. Oxidation stains and small chunks of metal were found along the north and south walls of the burial container, but these could not be further identified. They may be the remnants of coffin or casket handles.

Burial Orientation: East-west; head to east. This is an unusual orientation for historic 
Euro-American graves in Texas because most are oriented with the head to the west.

Body Position: The individual appeared to be in an extended, supine position. The position of the hands could not be determined.

Personal Items: A fragment of deteriorated leather was recovered. It lay on top of the distal end of the left tibia. It was $15.5 \mathrm{~cm}$ (6.1 inches) long, $8.5 \mathrm{~cm}$ (3.36 inches) wide, and up to $1.0547 \mathrm{~cm}$ (0.4 inches) thick.

\section{Osteological Characteristics}

Preservation/Taphonomy: The skeletal remains were poorly preserved, fragmented, and incomplete. Cortical surfaces and overall bone structure were significantly deteriorated. Few articular surfaces were present. The skull and much of the right side of this burial were destroyed by the Gradall. The left femur had rotated laterally so its posterior surface faced up and its head pointed laterally.

Sex: Indeterminate.

Age: Adult. The few epiphyses present show complete fusion. Overall robusticity is also consistent with an adult.

Skeletal Inventory: The skeletal remains consist of fragments of the shafts of the left humerus, radius, and ulna; the diaphysis and head of the left femur; fragments of the shaft and the lateral condyle of the right femur; fragments of the shafts of the right and left tibiae and fibulae; at least three left ribs (numbers 3-10); part of the left ilium with a portion of the acetabulum; the left patella; one left metatarsal; the left talus with part of the superior articularandposterior calcaneal articular surfaces present.

Dental Inventory: No teeth are present.

Skeletal Nonmetrics: Not observable.

Dental Nonmetrics: Not applicable.

\section{Skeletal Pathology}

Degenerative: Not observable.

Traumatic: Not observable.

Infectious: Not observable.

Neoplasm: Not observable.

Metabolic and Hematological: Not observable.

Other: Not observable.

Dental Pathology: Not applicable.

Other: Not applicable.

\section{BURIAL 3}

Burial 3 is interpreted as the grave of Oscar Abstein and a young child, both of whom died in 1884 and whose remains were re-interred in this location in 1892. All historical and archeological evidence indicates this is a secondary burial-a re-interment of disarticulated and presumably incomplete remains. Thus, this burial is significantly different from the other two.

\section{Mortuary Characteristics}

Grave Marker: The fragments of Oscar Abstein's headstone were in two different locations, having been separated and set into two different concrete slabs. The main portion of the headstone (see Figure 4) was located about $2 \mathrm{~m}$ northeast of this grave, and the other base fragments were found about $1.5 \mathrm{~m}$ to the northwest (see Figure 6). A buried plinth also was found about $80 \mathrm{~cm}$ directly west of this grave, and it is considered to be directly associated. It was 48 inches below the top of the retaining wall, and only about $60 \mathrm{~cm}$ higher than the bottom of this grave. This plinth was made of white limestone, neatly cut into a rectangular block measuring $48.3 \mathrm{~cm}$ long, $15.2 \mathrm{~cm}$ tall, and $24.1 \mathrm{~cm}$ wide (19.0x6.0x9.5 inches). A rectangular slot cut into its top measures $37.5 \mathrm{~cm}$ long by $6.4 \mathrm{~cm}$ wide (14.75x2.5 inches). Notably, Oscar Abstein's headstone measures $35.6 \mathrm{~cm}$ wide and would fit perfectly into this plinth.

Oscar Abstein's headstone is neatly inscribed in German as follows: ${ }^{1}$

$$
\begin{gathered}
{[\ldots] \text { r } \sim \text { t in fremder }} \\
{[\ldots] \text { un fern von den }} \\
{[\ldots] \sim \text { nser theurer }} \\
\text { A [...]rwandter } \\
\text { OSCARABSTEIN, } \\
\sim \text { Geb. } \\
\text { 20, Apr il 1846, } \\
\text { Ge st. } \\
\text { 10, Juli } 1884 \\
\text { [?]t ruhe sei asche }
\end{gathered}
$$

${ }^{1} \mathrm{~A}$ “ " indicates a break in the stone, and “[...]" indicates a missing or illegible portion of the inscription. The name is enclosed inside a rectangular banner. The first eight lines appear on the six headstone fragments cemented together in the eastern marker (see Figure 4), and the bottom line appears on the two fragments cemented together in the western marker. 
The English translation of Abstein's inscription, done in January 2004 by Kenn Knopp (German Heritage Foundation, Fredericksburg, Texas), is as follows:

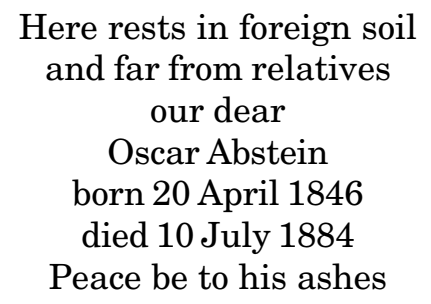

Burial Shaft Size and Depth: This grave is interpreted as a reinterment of remains from another grave, and it corresponds with historical evidence indicating Oscar Abstein's grave was moved in 1892. No grave shaft could be discerned, and the size, shape, and depth of this grave shaft are not known. This burial was very shallow in relation to the original ground surface, and its east side was truncated by the Gradall to an unknown extent because the shaft was not recognized. Some portion of the upper part of the grave was also truncated by the Gradall, but no burial remains could be found in the displaced fill thought to have come from this area. The lowest elevation of any material associated with the burial was $108 \mathrm{~cm}$ (42.5 in) below the top of the retaining wall. It is estimated that this grave was dug only 20 to $40 \mathrm{~cm}$ below the original ground surface.

Coffin / Casket Description: The type of burial container could not be determined because of poor preservation and partial destruction by the Gradall. Deteriorated and unidentifiable wood fragments delineated part of the north and south edges of the burial container, but no information concerning shape or size of the box could be gleaned from this. The area that the wood encompassed measured $70 \mathrm{~cm}$ (27.5 inches) by $40 \mathrm{~cm}$ (15.7 inches). Because this grave is shallow, it is likely that the remains were reinterred in a small box rather than a coffin or casket.

Coffin / Casket Hardware: Four machine-cut square nails and nail fragments were associated with the burial container. The soil matrix along the southern edge of the burial container also was iron rich, unlike the surrounding matrix. This orange ferric staining probably indicates the deteriorated remains of other metal hardware.

Body Orientation: The skeletal remains were completely disarticulated, as would be expected in a reinterment. Notably, the bones of an adult and a child were found.

Body Position: The remains of both of the individuals in this grave were displaced, representing a secondary burial (reinterment). The adult long bones that constituted most of the remains were oriented north-south and grouped tightly together. What remained of the child's cranial fragments were largely interspersed within this bundle.

Personal Items: None observed.

\section{Osteological Characteristics}

Preservation/Taphonomy: The skeletal remains were poorly preserved, fragmented, and incomplete. They were largely unobservable and occasionally unidentifiable. Cortical surfaces and overall bone structure were significantly deteriorated. No articular surfaces were present. Part of this burial might have been destroyed by the Gradall.

Sex: Indeterminate based on the skeletal remains.

Age: The postcranial remains and possibly some of the cranial remains are from an adult. Most of the cranial remains are from a subadult, likely a child aged $5-10$ years. These assessments are based on the overall size and robusticity of the bones.

Skeletal Inventory: The adult skeletal remains consist of possible fragments of the frontal and parietal(s); the distal portion of the shaft of the right and left humeri; an unsided rib (or clavicle) fragment; fragments of the shafts of the right and left femora; possible fragments of at least one tibia; an unidentified long bone-shaft fragment. The child's remains consisted of fragments of the frontal, parietals, and the occipital.

Dental Inventory: No teeth are present.

Skeletal Nonmetrics: Not observable.

Dental Nonmetrics: Not observable.

\section{Skeletal Pathology}

Degenerative: Not observable.

Traumatic: Not observable.

Infectious: Not observable.

Neoplasm: Not observable.

Metabolic and Hematological: Not observable.

Other: Not observable.

Dental Pathology: Not observable.

Other: Not observable. 



\section{ARCHEOLOGICAL AND BIOARCHEOLOGICAL ANALYSIS}

This chapter provides a more detailed discussion of the material culture and human remains recovered from Abstein Cemetery. Although the data are extremely limited, such a discussion will help to ground the cemetery and the people interred there within clearer temporal and social contexts and could make comparison with other mortuary sites easier and more accessible for future researchers.

\section{MORTUARY ARTIFACTS AND PERSONAL ITEMS}

Data on mortuary items were limited to the burial containers themselves and a number of metal machine-cut square nails used in their manufacture. The container for Burial 1 was a traditional hexagonal-shaped coffin. This burial also had an outer box that appeared to be rectangular. The container for Burial 2 was either a four-sided rectangular casket or a four-sided container that tapered toward the feet. The container for Burial 3, likely Oscar Abstein and a child, could not be determined. As mentioned above, it is likely that this reinterment used only a simple wooden box rather than a coffin or a casket.

Historical documents suggest the burials of the four people recovered at the Oscar Abstein cemetery occurred during the later 1800 s. The styles of burial containers documented at the cemetery are consistent with this period. Although the mass-produced casket was introduced in the mid-1800s and its use rapidly became more common and eventually replaced the coffin (Davidson 2000:245-247; Habenstein and Lamers 1955:270-274), the coffin continued in common use throughout the rest of the nineteenth century and into the 1920s. Further, the casket may have appeared later in Texas (Davidson 2000:247). The four-sided, tapered-to-feet burial container is uncommon but is documented within the same era of the transition from coffin to casket (e.g. Dockall, Powell, and Steele 1996; Rose 1985). Davidson (2000:245) suggests this style may be an expedient variation of the traditional coffin or one constructed by makers with limited carpentry skills.

During this period, the coffin or casket was often placed in the ground in a wooden exterior container, or outer box, like that recorded for Burial 1. Originally, the outer box was the crate in which the burial container had been shipped from the manufacturer. It was buried with the inner container as a means of disposal and as a method of protecting the burial container once it was placed in the ground (Habenstein and Lamers 1955:302-306). Generally, the outer box was rectangular, regardless of the shape of the burial container (Foster and Nance 2002:150).

In addition to the burial containers, the associated hardware, which was limited to machinecut square nails, is also consistent with interment in the latter part of the nineteenth century. The nine machine-cut square nails recovered from Burials 2 and 3 were all of a similar iron material and shape. Large scale manufacture of the round wire nail began in 1879 , and the wire nail gradually began to replace the machine-cut nail, picking up speed in the $1890 \mathrm{~s}$, when their cost became less prohibitive. In the manufacture of coffins and caskets, wire nails were introduced by at least the 1890 s, although machine-cut nails continued in use. Wire nails did not predominate in burial container construction until sometime between 1895 and 1900, and machine-cut nails were only completely replaced sometime in the 1900s (Davidson 2000:247-252), 
so that both types were in use together for a while around the turn of the century.

Both the burial container type and the associated hardware, then, are consistent with interments dating to the late nineteenth century. Oscar Abstein and the unidentified child are known to have been interred (1884) and reinterred (1892) during this time, and the other two burials were there before 1892 . The type and quality of Oscar Abstein and the child's original burial container is unknown. It is interesting to note, however, that enough time, energy, and likely money were expended on a quality headstone for Abstein, who was described only as a traveler. His relationship with the Gastmanns, on whose property he was buried, is unclear. But one wonders if Abstein was staying with the Gastmanns at the time he became ill and died, and it is notable that someone knew enough biographical information about him to put his dates of birth and death on his gravestone. The fact that all three burials (perhaps four originally) were placed far away from the Gastmann family cemetery (see Figure 2) suggests that none of them were directly related to the Gastmanns. This marginal relationship may help explain the lack of fancy mortuary hardware, which would have entailed more expense. It may also explain the possible tapered-to-feet container in which Burial 2 was interred, if Davidson (2000:245) is correct in his interpretation that this was an expedient form of coffin made by a person with limited carpentry skills. Such an expedient container would perhaps have been more appropriate for a person who was not related or otherwise close enough to the Gastmann family. It is significant, however, that care enough was taken to properly inter these people as prescribed by cultural norms.

Aside from the very deteriorated piece of leather associated with Burial 2, of which little further can be said, the only personal effects recovered were two bone or antler buttons found with the adult female in Burial 1. These buttons may have originally been covered in fabric or cloth that would have long since deteriorated in the grave. The location within the burial, in the middle left side of the upper torso, suggests these buttons might have been from a blouse or dress. The authors consulted several readily available mail-order (abbreviated and reprinted) catalogs from the period (e.g., Montgomery Ward \& Company 1895; Sears, Roebuck and Co., Inc. 1897).
Some oval bone buttons were listed, but no illustrations or descriptions of similar buttons were found. Bone buttons were fairly common during this period and have been documented at many cemeteries dating to the latter half of the nineteenth century (see e.g. Foster and Nance 2002; Peter et al. 2000). They are thought to have been "primarily used for utilitarian purposes such as underwear, particularly men's underwear, and suspender attachments" (Davidson 2000:410; see also Foster and Nance 2002:154).

\section{HUMAN REMAINS}

The osteological analyses provided little information about the people interred at Abstein Cemetery. Because of the poor condition of the skeletal remains, Burials 2 and 3 could be assigned only to broad age categories. Bioarcheological analysis is necessarily limited to the more complete Burial 1, which, however, exhibited few skeletal pathologies or anomalies. These included incipient signs of osteoarthritis, a possible carious lesion in the dentition, and shovel-shaped incisors and are discussed further below.

The poor condition of the skeletal remainsas well as the extremely limited number of people recovered-also obviates any discussion of population level dynamics, such as paleodemographic or paleoepidemiological trends evident within the sample. Comparison with other samples would likewise be futile. It is not clear what segment of the greater population these individuals were derived from or what their relation to one another or with other populations in terms of pathology or demography. For other cemetery samples from Texas in comparable periods, the reader is encouraged to refer to Foster and Nance (2002), Cooper et al. (2000), Tiné and Boyd (2003), and Tiné et al. (2002) and further references therein.

The slight lipping on the margins of the joint in Burial 1 may be attributable to an early stage of osteoarthritis. Osteoarthritis is one of the most common pathologies observed in skeletal remains from archeological sites (Rogers et al. 1987:185), and its prevalence in modern populations is likewise high, with at least one study indicating almost all people older than 65 show some signs of osteoarthritis (Solomon 2001:1410 in Ortner 2003:545). It becomes manifest prima- 
rily in the fourth decade of life. Osteoarthritis is characterized by joint cartilage degeneration and loss of joint space eventually leading to exposure of the bone surface within the joint and bone-on-bone contact. Its etiology is complex and apparently largely idiopathic and involves anatomical, physiological, biomechanical, and genetic factors. Skeletal manifestations that osteologists may observe include new bone (osteophytic) formation, or lipping, at the joint margins, sclerosis in the subchondral compact bone and the trabeculae, subchondral cysts, porosity of the subchondral bone, and eburnation of the joint surface (Aufderheide and Rodríguez-Martín 1998:93-96; Ortner 2003:545-547; Rogers and Waldron 1995:Chapter 4; Rogers et al. 1987:179_ 183).

It should be noted that marginal lipping can occur without the loss of joint space required for a diagnosis of osteoarthritis, and marginal lipping is an almost universal age-related change not necessarily related to osteoarthritis (Cockburn et al. 1979:75; Rogers and Waldron 1995:Chapters 3 and 4).

The presence of very slight osteophytic lipping in an person as young as Burial 1 does not suggest abnormal biomechanical stress on the skeleton of this individual, and its occurrence throughout the skeleton suggests it is more likely age-related. Although no other signs of osteoarthritis were observed, the joint surfaces were often deteriorated, and pitting may have been obscured. Pitting, however, can also occur in the absence of osteoarthritis (Rogers and Waldron 1995:36).

The presence of the single possible carious lesion likewise does not suggest overall poor oral health. Caries is a disease in which bacteria in the mouth secrete acids and proteases during metabolism that dissolve the roots and the enamel of the teeth. Surfaces of the teeth where food can become trapped, such as the occlusal surfaces of the premolars and molars and just below the interproximal facets of adjacent teeth, are more prone to cariogenesis (Langsjoen 1998:403-404; Ortner 2003:590). Like osteoarthritis, caries is one of the more prevalent diseases recognized in the archeological record (Langsjoen 1998:403). In fact, the lack of antemortem tooth loss and any other condition related to hygiene, such as calculus deposits and alveolar bone loss related to periodontal disease, suggests an overall healthy dentition, particularly for a woman who was likely in her thirties when she died. Wear on the occlusal surface was also within a normal range.

Shovel-shaped incisors are more commonly associated with Native Americans and people of Asian descent. They have been well-documented in Caucasians, although there is some disagreement about prevalence (compare e.g. Rhine 1990; Hinkes 1990). Most studies agree that its development in Caucasians is less pronounced than in Asians (e.g. Hinkes 1990). 



\section{SUMMARY AND SYNTHESIS}

Necessitated by continued urban growth in the greater Houston area, ongoing improvements to Interstate Highway 10 (IH-10) in west Houston are being undertaken by the Texas Department of Transportation (TxDOT). Recognizing that these improvements would disturb the Abstein cemetery, situated at the northwest intersection of Eldridge Parkway and the westbound frontage road of IH-10, TxDOT initiated a historical research project. Documentary and oral history evidence suggested the Abstein cemetery contained several historic graves, dating to the late $1800 \mathrm{~s}$. One of the graves belonged to Oscar Abstein, the cemetery's namesake, who died in 1884. Abstein, a German-speaking immigrant who would likely have felt at home in the growing German community around Bear Creek in what is now west Houston, was apparently travelling through the area and staying at a nearby house when he and an unidentified child fell sick and died. Both were interred on the property of the Gastmann family. A deed record dating to 1892 shows that sometime after December of that year, Abstein's remains were disinterred and moved slightly south, nearer two other unidentified graves, to make way for the Missouri, Kansas \& Texas Railway, but no further mention is made of the child. After that, the names of the people interred there and their exact locations were largely lost. The site was memorialized in recent history when someone gathered the fragments of Oscar Abstein's broken headstone and cemented them into two concrete slabs thinking that they represented two different grave markers. This, along with placement of two white wooden crosses to mark two presumed grave locations, occurred in 1999 or not too long before.

TxDOT contracted Prewitt and Associates,
Inc. (PAI), to exhume any graves present in the Abstein Cemetery, recover and analyze the skeletal and material remains, and, after identifying an appropriate cemetery, reinter the remains. Mechanical scraping revealed three graves. Hand excavation and documentation of two graves showed that they contained remains of two unidentified adults. One was a female aged $30-40$ years at death, and we know nothing about the other person. These are likely the two graves mentioned in the 1892 deed transfer to the Katy railroad, which required that Abstein's remains be moved closer to these two graves. The third grave that was excavated contained the disarticulated and incomplete remains of an adult and a child. These appear to be the reinterred remains of Oscar Abstein and the child with whom he died. Although osteological analysis did not reveal any biographic information on these individuals, Abstein's headstone reveals he died at age 38 .

The archeological investigations corroborate the historic records that indicate that both Abstein and the child were disinterred after December 1892 by the Katy railroad, but the evidence indicates that they were later reinterred together in a single grave. It is interesting to note they were disinterred at the same time and reinterred together, but no mention of this is made in the deed transfer. It is possible they were originally interred together at the time of their deaths, in which case it would have been necessary for the railroad to move only one grave. Archival research and oral history have not clarified the relationship between Abstein and the child. For example, it is implied, but not entirely clear, that Abstein and the child were travelling together. If they were travelling together and perhaps were related, it would make 
more sense that they would have been originally interred together. But if they are related, it begs the question of why no further mention is made of the child in the historical record or on Abstein's gravestone. That they both died at about the same time also seems curious.

It may be surmised-but is far from proven-that all four of the people buried in the Abstein Cemetery were of German ancestry. This is likely given the proximity of the three graves, the fact that Oscar Abstein was probably German, and the fact that most of the early settlers in the immediate area were German. But the small number of individuals recovered and the overall poor condition of the skeletal remains allow for little insight into the demography and health of the local population during the later $1800 \mathrm{~s}$. The extent and severity of changes on the joint margins observed on Burial 1 are not atypical or outstanding. Neither is the single possible carious lesion observed in this person's teeth. Likewise, the burial containers and associated machine-cut square nails found with Burials 1 and 2 are typical mortuary furnishings during the latter half of the nineteenth century and provide little further understanding of the funerary industry or funerary customs at the time.

The significance of the fact that the person in Burial 2 was interred with head to the east, rather than the common head-to-the-west orientation, is not known. Jordan (1982:30) notes that, "Nearly all southern folk cemeteries have the graves aligned on an east-west axis, and burials are made with feet to the east." Although this is the most common, nearly universal, Christian tradition in the southern United States, its origins are not completely clear. Many people believe, for example, that such burials allow the deceased to rise up to face the rising sun or Christ on Judgement Day. Burials at other orientations, particularly a north-south alignment, were often reserved for "those who sinned extraordinarily" (Jordan 1982:30). But there are often exceptions to the general head-to-the-west rule, and Jordan (1982:95) has observed German cemeteries in Texas where grave orientation varies. In some cemeteries, the graves are laid out perpendicular to a main road and all oriented askew, or graves on opposite sides of the road may be oriented differently. This does not seem to be the case for Burial 2, however, and the reason for its unusual orientation is not known.

\section{REBURIAL}

After the burials were exhumed and analyzed, all of the human remains and associated materials were placed in individual reburial boxes. The three reburial boxes-one containing the remains of Oscar Abstein and the child, and the other two containing the remains of the two unidentified persons - were re-interred in a single grave plot at Washington Cemetery near downtown Houston on November 21, 2003. PAI archeologists placed the three boxes inside the new grave shaft, with the head of each box pointing west and the foot end to the east. The two plinths, associated with Burials 1 and 3, were placed in the grave shaft as well.

The fragments of Oscar Abstein's headstone, still encased in concrete, were left under the care of Richard Ambrus (vice president and general manager of Glenwood Cemetery, Inc.). These fragments will be removed from the concrete slabs, reconstructed, and placed at the head of the grave. The project plans also require that TxDOT purchase a new funerary monument to place over the reinterment grave. It will commemorate all four of the people who were originally buried at the Abstein Cemetery. The new grave plot where these remains are reburied is Space 6, Section I, Lot 19, West 1/2, at Washington Cemetery. Everything considered, the reburial plot beneath a large oak tree in the quiet southwest corner of Washington Cemetery is a much more peaceful place than the former spot along Interstate Highway 10. 


\section{REFERENCES CITED}

Aronow, Saul

1976 Geology. In Soil Survey of Harris County, Texas, pp. 43-45. United States Department of Agriculture, Soil Conservation Service, in cooperation with the Texas Agricultural Experiment Station and the Harris County Flood Control District.

Acsádi, Gy., and J. Nemeskéri

1970 History of Human Life Span and Mortality. Akadémiai Kiadó, Budapest.

Aufderheide, Arthur C., and Conrado RodríguezMartín

1998 The Cambridge Encyclopedia of Human Paleopathology. Cambridge University Press, Cambridge.

Beverly, Trevia Wooster (compiler)

2001 At Rest: A Historical Directory of Harris County, Texas[,], Cemeteries (1822-2001). Revised edition. Tejas Publications \& Research, Houston, Texas.

Brothwell, Don R.

1981 Digging Up Bones: The excavation, treatment, and study of human skeletal remains. 3rd edition. Cornell University Press, Ithaca.

Browning, Emilia

2001 Interview with Emilia Browning, September 24, 2001, by unidentified TxDOT employee. Interview notes in files of the Archeological Studies Program, Environmental Affairs Division, Texas Department of Transportation, Austin.

Buikstra, Jane E., and Douglas H. Ubelaker (editors)

1994 Standards for Data Collection from Human Skeletal Remains. Research Series No. 44. Arkansas Archeological Survey, Fayetteville.

Bureau of Economic Geology

1968 Geologic Atlas of Texas, Houston Sheet. Bureau of Economic Geology, The University of Texas at Austin.
Cockburn, Aidan, Howard Duncan, and Jeanne M. Riddle

1979 Arthritis, ancient and modern: guidelines for field workers. Henry Ford Hospital Medical Journal 27(1):74-79.

Cooper, Judy H., Angela L. Tiné, Marsha Prior, Charles M. Clow, David Shanabrook, and Ed Salo

2000 Cultural Resources and Bioarcheological Investigations at the Dallas Convention Center and Pioneer Cemetery, Dallas, Texas. Miscellaneous Reports of Investigations No. 205. Geo-Marine, Inc., Plano, Texas.

Davidson, James M.

2000 The Development of Freedman's Cemetery. In Freedman's Cemetery: A Legacy of a Pioneer Black Community in Dallas, Texas, vol. 2, edited by Duane E. Peter, Marsha Prior, Melissa M. Green, and Victoria G. Clow, pp. 233-407. Special Publication No. 6. Geo-Marine, Inc., Plano, Texas. Submitted to Environmental Affairs Division, Texas Department of Transportation, Austin.

Dockall, Helen Danzeiser, Douglas K. Boyd, Martha Doty Freeman, Rolando L. Garza, Kevin E. Stork, Karl W. Kibler, and Joan E. Baker

1996 Confederate Veterans at Rest:Archeological and Bioarcheological Investigations at the Texas State Cemetery, Travis County, Texas. Reports of Investigations No. 107. Prewitt and Associates, Inc., Austin.

Dockall, Helen Danzeiser, Joseph F. Powell, and D. Gentry Steele

1996 Home Hereafter: An Archaeological and Bioarchaeological Analysis of an Historic African-American Cemetery (41GV125). Reports of Investigations No. 5. Center for Environmental Archaeology, Texas A\&M University, College Station.

Evening Journal (Houston, Texas)

Foster, Eugene, and Linda A. Nance (editors) 2002 Archaeological Investigation Report: Allen 
Parkway Village, 41HR886, Houston, Harris County, Texas. Document No. 020018. PBS\&J, Austin.

Freeman, Martha Doty

2002 Archival Research on Reported Burials within a Portion of Targeted Areas of the Interstate Highway 10 Right of Way, West Houston, Harris County, Texas. Report submitted to Archeological Studies Program, Environmental Affairs Division, Texas Department of Transportation, Austin, by Prewitt and Associates, Inc., Austin.

Galveston, Texas, city directories

Galveston County, Texas

Deed Records

Declaration of Intent

Index to Declaration of Intent

Index to Naturalization Records

Naturalization Service Petition and Record

Probate Records

Record of Naturalization Petitions

Geue, Ethel Hander

1970 New Homes In a New Land: German Immigration to Texas, 1847-1861. Texian Press, Waco, Texas.

Geue, Chester W., and Ethel Hander Geue 1982 A New Land Beckoned: German Immigration to Texas, 1844-1847. Genealogical Publishing Co., Inc., Baltimore, Maryland.

Gill, George W., and Stanley Rhine (editors)

1990 Skeletal Attribution of Race: Methods for Forensic Anthropology. Anthropological Papers No.4, Maxwell Museum of Anthropology, University of New Mexico, Albuquerque.

Glazier, Ira A., and P. William Filby (editors) 1988- Germans to America: Lists of Passengers Arriving at U.S. Ports, 1850-1855. Scholarly Resources, Inc., Wilmington, Delaware.

Guendling, Randall, Murray K. Marks, Jerome C. Rose, and Lawrence Gene Santeford

1985 Methodology. In Gone to a Better Land: A Biohistory of a Rural Black Cemetery in the Post-Reconstruction South, edited by Jerome C. Rose. Research Series No. 25 Arkansas Archaeological Survey, Fayetteville.

Habenstein, Robert W., and William M. Lamers
1955 The History of American Funeral Directing. 3rd ed. National Funeral Directors Association, Milwaukee.

Harris County, Texas

Appraisal District Records

Declaration of Intent, 1899 to 1903, Vol. 1

Deed Records

District Court Records

Index to Naturalization Records, May 23, 1837, to March 5, 1913

Probate Records

Oaths of Allegiance, 1892

Record of Final Naturalization, 1886 to June 1, $1892 ; 1903$ to 1906 , Vol. 1

Records of Oaths of Allegiance, Vol. 1, 1903 to 1906

Hinkes, Madeleine J.

1990 Shovel Shaped Incisors in Human Identification. In Skeletal Attribution of Race: Methods for Forensic Anthropology, edited by George W. Gill and Stanley Rhine, pp.21-26. Anthropological Papers No.4, Maxwell Museum of Anthropology, University of New Mexico, Albuquerque.

Houston, Texas, city directories

Jordan, Terry G.

1982 Texas Graveyards: A Cultural Legacy. University of Texas Press, Austin.

Koehn, Emil

2001 Interview with Emil Koehn, April 23, 2001, by unidentified TxDOT employee. Interview notes in files of the Archeological Studies Program, Environmental Affairs Division, Texas Department of Transportation, Austin.

Langsjoen, Odin

1998 Diseases of the dentition. In The Cambridge Encyclopedia of Human Paleopathology, edited by Arthur C. Aufderheide and Conrado RodríguezMartín, pp.393-412. Cambridge University Press, Cambridge.

Mann, Robert W., Steven A. Symes, and William M. Bass

1987 Maxillary suture obliteration: aging the human skeleton based on intact or fragmentary maxilla. Journal of Forensic Sciences 32(1):148-157.

Mann, Robert W., Richard L. Jantz, William M. Bass, and Patrick S. Willey

1991 Maxillary suture obliteration: a visual 
method for estimating skeletal age. Journal of Forensic Sciences 36(3):781-791.

Meindl, Richard S., and C. Owen Lovejoy

1985 Ectocranial suture closure: a revised method for the determination of skeletal age at death based on the lateral-anterior sutures. American Journal of Physical Anthropology 68:57-66

Miles, A. E. W.

1958 The assessment of age from the dentition. Proceedings of the Royal Society of Medicine 51:1,057-1,060.

1962 Assessment of the ages of a population of Anglo-Saxons from their dentitions. Proceedings of the Royal Society of Medicine 55:881-886

Montgomery Ward \& Company

1895 Catalogue and Buyers' Guide No. 57, Spring and Summer. Reprinted in 1969 by Dover Publications, Inc., New York.

Murphy, Thomas

1959a The changing pattern of dentine exposure in human tooth attrition. American Journal of Physical Anthropology 17:167-178.

1959b Gradients of dentine exposure in human molar tooth attrition. American Journal of Physical Anthropology 17:179-186.

Ortner, Donald J.

2003 Identification of Pathological Conditions in Human Skeletal Remains. Second Edition. Academic Press, San Diego.

Peter, Duane E., Marsha Prior, Melissa M. Green, and Victoria G. Clow (editors)

2000 Freedman's Cemetery: A Legacy of A Pioneer Black Community in Dallas, Texas. 2 volumes. Archeological Studies Program Report No. 21, Environmental Affairs Division, Texas Department of Transportation, Austin and Special Publication No. 6, Geo-Marine, Inc., Plano.

Rhine, Stanley

1990 Non-Metric Skull Racing. In Skeletal Attribution of Race: Methods for Forensic Anthropology, edited by George W. Gill and Stanley Rhine, pp. 9-20. Anthropological Papers No.4, Maxwell Museum of Anthropology, University of New Mexico, Albuquerque.

Rogers, Juliet, and Tony Waldron

1995 A Field Guide to Joint Disease in Archaeol- ogy. John Wiley and Sons, Chichester.

Rogers, Juliet, Tony Waldron, Paul Dieppe, and Iain Watt

1987 Arthropathies in Palaeopathology: The basis of classification according to most probable cause. Journal of Archaeological Science 14:179-183.

Rose, Jerome C. (editor)

1985 Gone to a Better Land: A Biohistory of a Rural Black Cemetery in the PostReconstruction South. Research Series No. 25. Arkansas Archaeological Survey, Fayetteville.

Scott, E. C.

1979 Dental wear scoring technique. American Journal of Physical Anthropology 51:213217.

Scott, G. Richard, and Christy G. Turner II

1997 The Anthropology of Modern Human Teeth. University Press, Cambridge.

Sears, Roebuck and Co., Inc.

1897 Catalogue No. 104, edited by Fred I. Israel. Reprinted in 1993 by Chelsea House Publishers, New York.

Smith, B. Holly

1984 Patterns of molar wear in hunter-gatherers and agriculturalists. American Journal of Physical Anthropology 63:39-56.

Solomon, L.

2001 Clinical Features of Osteoarthritis. In Kelley's Textbook of Rheumatology, 6 th edition, edited by Shaun Ruddy, Edward D. Harris, Jr., and Clement B. Sledge, pp. 1,409-1,418. Saunders, Philadelphia.

Texas State Highway Department

1931 Map entitled: "Plan and Profile of Proposed State Highway, Harris County, Highway No. 73 from Campbell Road to Addicks." State of Texas, Highway Department. Handwritten note states: "Completed Sept. 1931." Plan is signed as "Correct" by Jim Douglas, Division Engineer. Scale 1 inch $=2,000$ feet.

1954 Map entitled: "Plans of Proposed State Highway Improvement, Harris County, U.S. Highway 90 from 0.7 Mile West of Campbell Road to Addicks (Grading and Drainage Structures), Final Plans." State Highway Department. Federal Aid 
Project F.I. 1039 (6). "Correct Feb. 5,1954. Recommended for Approval 2/11, 1954." Scale $1 \mathrm{inch}=2,640$ feet.

1965 Map entitled: "Plans of Proposed State Highway Improvement, Harris County, Interstate Highway 10 from Addicks, East to West End of the West Belt Interchange (Grading, Structures, Cement Stabilized Base, Concrete Pavement, Asph. Conc. Pvt, Signing and Median Barrier Fence)."State Highway Department. Federal Aid Project I 10-7(116)760. Correct July 26, 1965. Scale 1 inch = 1,000 feet.

Tiné, Angela L., and Douglas K. Boyd

2003 Archeological Excavation and Reburial of Unmarked Historic Graves in the Pioneer Cemetery (41BO202), Brazoria County, Texas. Prewitt and Associates, Inc. Reports of Investigation, Number 139.

Tiné, Angela L., Judy H. Cooper, and Michelle Wurtz 2002 Archeological and Bioarcheological Investigations at Potter's Field / Greenwood Cemetery Along Clyde Lane, Dallas, Texas. Geo-Marine, Inc., Miscellaneous Reports of Investigations Number 241.

Turner, Christy G. II, Christian R. Nichol, and G. Richard Scott
1991 Scoring procedures for key morphological traits of the permanent dentition: The Arizona State University Dental Anthropology System. In Advances in Dental Anthropology, edited by Marc A. Kelley and Clark Spenser Larsen. New York, WileyLiss. pp.13-31.

U.S. Bureau of the Census, Texas (all counties by index)

1860 Harris County, Texas

Victoria County, Texas

1870 Bell County, Texas

Harris County, Texas

1880 Anderson County, Texas

Cass County, Texas

Galveston County, Texas

Grayson County, Texas

Harris County, Texas

Kaufman County, Texas

Robertson County, Texas

San Saba County, Texas

Tarrant County, Texas

United States Department of Agriculture

1976 Soil Survey of Harris County, Texas. United States Department of Agriculture, Soil Conservation Service, in cooperation with the Texas Agricultural Experiment Station and the Harris County Flood Control District. 


\section{APPENDIX A: Glossary of Technical Terms}


Note: This appendix defines the most common technical terms associated with the archeological recovery, analysis, and interpretation of human remains from historic graves. No attempt is made to define all of the medical and osteological terms used in this report.

Age Determination: Estimation of age at death, usually in years, of a person through growth and development-related markers in the human skeleton, such as the formation and eruption of teeth or fusion of the ends of long bones.

Bioarcheology: A discipline that emphasizes "the human biological component of the archeological record" (Clark Spencer Larsen, 1992, Bioarcheology: Interpreting Behavior from the Human Skeleton, p. 3). In studies of historic cemeteries, this discipline entails the analysis of any human remains exhumed from the cemetery and the incorporation of this information into the larger set of information gathered from the cemetery, such as personal effects, coffin type, and mortuary hardware.

Biological Affinity and Ethnicity: In osteology, biological affinity refers to the geographic ancestry of a person as assessed by distinctive and inherited traits in the skeleton. Sometimes referred to as race. Ethnicity is a broader term that encompasses biological affinity as well as cultural and social characters that typify an individuals and the group to which they belong.

Biomechanical Stress: In osteology, refers to the demands placed on bone by various activities engaged in by a person during his lifetime. An example of biomechanical stress might be the strain on the bones of the legs of someone who runs regularly.

Burial: see Interment

Casket: see Coffin

Coffin vs. Casket: Two types of burial containers used to bury people. A coffin is six-sided, or hexagonal, in shape and widest at the shoulders. A casket is four-sided, or rectangular, in shape.

Cranial Measurements: Measurements taken between various landmarks on the human skull, usually used to determine such things as sex, biological affinity, and so on.

Demography: The study of human populations, particularly in relation to size, density, distribution, and age structure.

Dental Inventory: In osteological analyses, this typically refers to an inventory of the teeth present in the skeleton of one individual.

Ethnicity: see Biological Affinity.

Exhume: To remove a burial from the ground.

Infection: Pathological condition in the body caused by the presence of agents such as bacteria. In bone, infection may be evident either through the presence of abnormal, new bone formation or destruction of the bone.

Interment: The burial of a person, including the physical remains and the burial container.

Metric Attributes: Aspects of the human skeleton that can be measured, such as the length of a long bone or the width of the skull.

Mortuary Hardware: Items used in the construction of a coffin or casket-such as nails, tacks, thumbscrews, and handles-and the items used to decorate the coffin or casket, such as nameplates.

Nonmetric Attributes: Morphological characters of the human skeleton that are not measured but are described or recorded in terms of their presence or absence. Examples include the type of cusp patterns on molars and the presence or absence of extra bones in the cranium. Some nonmetric attributes are thought to be at least partly inherited.

Osteology: The study of bone and the skeleton.

Paleopathology: The study of diseases and their patterning in past populations.

Personal Effects: Items belonging to an person that are buried with that individual. Items commonly found in historic graves include buttons from the clothing the person was wearing when he was buried, hairpins, and jewelry. 
Postcranial Measurements: Measurements of the skeleton (see metric attributes) excluding the skull, usually used to estimate a person's stature, determine sex, and so on.

Reburial: (also called reinterment) Burial of a person after exhumation.

Relocate vs. Re-locate: Re-locate means to find again, and relocate means to move to a new location.

Sex Determination: In the analysis of the human skeleton, determination of the sex of a person using physical characters differing between men and women, such as the shape of the pelvis and metric attributes.

Skeletal Inventory: An inventory of all the bones in a single burial.

Socioeconomic: In anthropological studies, refers to the social status of an individual, based on economic factors such as occupation and income, and also factors such as family and social groups affiliation and biological affinity.

Trauma: An injury or wound. A fracture of one of the bones of the arm would be an example of trauma to the skeleton. 

APPENDIX B: Skeletal Inventories and Observations 
Table B.1. Skeletal inventory

\begin{tabular}{|c|c|c|c|c|}
\hline Element & Burial 1 & Burial 2 & Burial $3 * *$ & Burial $3 * * *$ \\
\hline L frontal & 2 & - & $3(?)$ & 3 \\
\hline $\mathrm{R}$ frontal & 2 & - & $3(?)$ & 3 \\
\hline $\mathrm{L}$ parietal & 2 & - & $3(?)$ & 3 \\
\hline $\mathrm{R}$ parietal & 2 & - & $3(?)$ & 3 \\
\hline L occipital & 2 & - & - & 3 \\
\hline $\mathrm{R}$ occipital & 2 & - & - & 3 \\
\hline L temporal & - & - & - & - \\
\hline $\mathrm{R}$ temporal & - & - & - & - \\
\hline L TMJ & - & - & - & - \\
\hline R TMJ & - & - & - & - \\
\hline L sphenoid & - & - & - & - \\
\hline R sphenoid & - & - & - & - \\
\hline L zygomatic & 2 & - & - & - \\
\hline $\mathrm{R}$ zygomatic & 2 & - & - & - \\
\hline L maxilla & - & - & - & - \\
\hline $\mathrm{R}$ maxilla & - & - & - & - \\
\hline L palatine & - & - & - & - \\
\hline $\mathrm{R}$ palatine & - & - & - & - \\
\hline L mandible & 2 & - & - & - \\
\hline $\mathrm{R}$ mandible & 2 & - & - & - \\
\hline L clavicle & 1 & - & - & - \\
\hline $\mathrm{R}$ clavicle & 2 & - & - & - \\
\hline L scapula body & 3 & - & - & - \\
\hline R scapula body & 3 & - & - & - \\
\hline L scapula glenoid & - & - & - & - \\
\hline $\mathrm{R}$ scapula glenoid & 1 & - & - & - \\
\hline L patella & - & 2 & - & - \\
\hline $\mathrm{R}$ patella & 1 & - & - & - \\
\hline L sacrum & - & - & - & - \\
\hline $\mathrm{R}$ sacrum & - & - & - & - \\
\hline L ilium & 3 & 3 & - & - \\
\hline R ilium & 3 & - & - & - \\
\hline L ischium & - & - & - & - \\
\hline $\mathrm{R}$ ischium & 3 & - & - & - \\
\hline L pubis & - & - & - & - \\
\hline $\mathrm{R}$ pubis & - & - & - & - \\
\hline $\mathrm{L}$ acetabulum & 2 & 2 & - & - \\
\hline $\mathrm{R}$ acetabulum & 2 & - & - & - \\
\hline L auricular surf. & - & - & - & - \\
\hline $\mathrm{R}$ auricular surf. & - & - & - & - \\
\hline C1 centrum & - & - & - & - \\
\hline vC1 neural arch & - & - & - & - \\
\hline C2 centrum & - & - & - & - \\
\hline C2 neural arch & - & - & - & - \\
\hline C3-6 centrum* & - & - & - & - \\
\hline C3-6 neural arch* & - & - & - & - \\
\hline C7 centrum & - & - & - & - \\
\hline C7 neural arch & - & - & - & - \\
\hline T1-T9 centrum* & - & - & - & - \\
\hline T1-T9 neural arch* & $5 / 0$ & - & - & - \\
\hline
\end{tabular}


Appendix B: Skeletal Inventories and Observations

Table B.1, continued

\begin{tabular}{|c|c|c|c|c|}
\hline Element & Burial 1 & Burial 2 & Burial $3 * *$ & Burial $3 * * *$ \\
\hline T10 centrum & - & - & - & - \\
\hline T10 neural arch & - & - & - & - \\
\hline T11 centrum & - & - & - & - \\
\hline T11 neural arch & - & - & - & - \\
\hline T12 centrum & - & - & - & - \\
\hline T12 neural arch & - & - & - & - \\
\hline L1 centrum & - & - & - & - \\
\hline L1 neural arch & - & - & - & - \\
\hline L2 centrum & - & - & - & - \\
\hline L2 neural arch & - & - & - & - \\
\hline L3 centrum & - & - & - & - \\
\hline L3 neural arch & - & - & - & - \\
\hline L4 centrum & - & - & - & - \\
\hline L4 neural arch & - & - & - & - \\
\hline L5 centrum & - & - & - & - \\
\hline L5 neural arch & & - & - & - \\
\hline Unidentified lumbar neural arch & $1 / 0$ & - & - & - \\
\hline Sternum-manubrium & - & - & - & - \\
\hline Sternum-body & - & - & - & - \\
\hline L rib 1 & - & - & - & - \\
\hline $\mathrm{R}$ rib 1 & - & - & - & - \\
\hline L rib 2 & 3 & - & - & - \\
\hline $\mathrm{R}$ rib 2 & 3 & - & - & - \\
\hline L ribs $3-10 *$ & $7 / 0$ & $3 / 0$ & - & - \\
\hline $\mathrm{R}$ ribs $3-10 *$ & $7 / 0$ & - & - & - \\
\hline L rib 11 & - & - & - & - \\
\hline $\mathrm{R}$ rib 11 & 3 & - & - & - \\
\hline L rib 12 & - & - & - & - \\
\hline $\mathrm{R}$ rib 12 & - & - & - & - \\
\hline Unsided rib frags.* & - & - & $1 / 0$ & - \\
\hline L hum. proximal epiphysis & - & - & - & - \\
\hline L hum. diaphysis prox. $1 / 3$ & 1 & 3 & - & - \\
\hline L hum. diaph. middle $1 / 3$ & 1 & 3 & 3 & - \\
\hline L hum. diaph. distal 1/3 & 1 & 3 & 3 & - \\
\hline L hum. dist. epiph. & - & - & - & - \\
\hline R hum. prox. epiph. & - & - & - & - \\
\hline R hum. diaph. prox. 1/3 & 1 & - & - & - \\
\hline $\mathrm{R}$ hum. diaph. middle $1 / 3$ & 1 & - & 3 & - \\
\hline $\mathrm{R}$ hum. diaph. dist. $1 / 3$ & 1 & - & 3 & - \\
\hline $\mathrm{R}$ hum. dist. epiph. & - & - & - & - \\
\hline L rad. prox. epiph. & - & - & - & - \\
\hline L rad. diaph. prox. $1 / 3$ & 1 & 3 & - & - \\
\hline $\mathrm{L}$ rad. diaph. middle $1 / 3$ & 1 & 3 & - & - \\
\hline $\mathrm{L}$ rad. diaph. dist. $1 / 3$ & 1 & 3 & - & - \\
\hline L rad. dist. epiph. & - & - & - & - \\
\hline $\mathrm{R}$ rad. prox. epiph. & - & - & - & - \\
\hline $\mathrm{R}$ rad. diaph. prox. $1 / 3$ & 1 & - & - & - \\
\hline $\mathrm{R}$ rad. diaph. middle $1 / 3$ & 1 & - & - & - \\
\hline $\mathrm{R}$ rad. diaph. dist. $1 / 3$ & 1 & - & - & - \\
\hline $\mathrm{R}$ rad. dist. epiph. & - & - & - & - \\
\hline L ulna prox. epiph. & 3 & - & - & - \\
\hline
\end{tabular}


Table B.1, continued

\begin{tabular}{|c|c|c|c|c|}
\hline Element & Burial 1 & Burial 2 & Burial $3 * *$ & Burial $3 * * *$ \\
\hline L ulna diaph. prox. 1/3 & 2 & 3 & - & - \\
\hline L ulna diaph. middle $1 / 3$ & 2 & 3 & - & - \\
\hline L ulna diaph. dist. $1 / 3$ & 2 & 3 & - & - \\
\hline L ulna dist. epiph. & - & - & - & - \\
\hline R ulna prox. epiph. & - & - & - & - \\
\hline $\mathrm{R}$ ulna diaph. prox. $1 / 3$ & 3 & - & - & - \\
\hline $\mathrm{R}$ ulna diaph. middle $1 / 3$ & 3 & - & - & - \\
\hline $\mathrm{R}$ ulna diaph. dist. $1 / 3$ & 3 & - & - & - \\
\hline R ulna dist. epiph. & - & - & - & - \\
\hline L femur prox. epiph. & 2 & 2 & - & - \\
\hline L femur diaph. prox. $1 / 3$ & 1 & 2 & - & - \\
\hline L femur diaph. middle $1 / 3$ & 1 & 3 & 3 & - \\
\hline L femur diaph. dist. $1 / 3$ & 1 & - & 3 & - \\
\hline L femur dist. epiph. & 2 & - & - & - \\
\hline $\mathrm{R}$ femur prox. epiph. & 1 & - & - & - \\
\hline $\mathrm{R}$ femur diaph. prox. $1 / 3$ & 1 & - & 3 & - \\
\hline $\mathrm{R}$ femur diaph. middle $1 / 3$ & 1 & 2 & 3 & - \\
\hline $\mathrm{R}$ femur diaph. dist. $1 / 3$ & 1 & 2 & - & - \\
\hline $\mathrm{R}$ femur dist. epiph. & - & 2 & - & - \\
\hline L tibia prox. epiph. & - & - & - & - \\
\hline L tibia diaph. prox. $1 / 3$ & 1 & 2 & - & - \\
\hline L tibia diaph. middle $1 / 3$ & 1 & 2 & 3 & - \\
\hline L tibia diaph. dist. $1 / 3$ & 1 & 2 & - & - \\
\hline L tibia dist. epiph. & - & - & - & - \\
\hline R tibia prox. epiph. & - & - & - & - \\
\hline $\mathrm{R}$ tibia diaph. prox. $1 / 3$ & 2 & 2 & - & - \\
\hline $\mathrm{R}$ tibia diaph. middle $1 / 3$ & 1 & 2 & - & - \\
\hline $\mathrm{R}$ tibia diaph. dist. $1 / 3$ & 2 & 2 & - & - \\
\hline $\mathrm{R}$ tibia dist. epiph. & - & - & - & - \\
\hline L fibula prox. epiph. & - & - & - & - \\
\hline L fibula diaph. prox. 1/3 & 1 & 2 & - & - \\
\hline L fibula diaph. middle $1 / 3$ & 1 & 2 & - & - \\
\hline L fibula diaph. dist. 1/3 & 1 & 2 & - & - \\
\hline L fibula dist. epiph. & - & - & - & - \\
\hline R fibula prox. epiph. & - & - & - & - \\
\hline $\mathrm{R}$ fibula diaph. prox. 1/3 & 2 & 3 & - & - \\
\hline $\mathrm{R}$ fibula diaph. middle $1 / 3$ & 1 & 3 & - & - \\
\hline $\mathrm{R}$ fibula diaph. dist. $1 / 3$ & 2 & 3 & - & - \\
\hline $\mathrm{R}$ fibula dist. epiph. & - & - & - & - \\
\hline L talus & - & 2 & - & - \\
\hline $\mathrm{R}$ talus & 2 & - & - & - \\
\hline L calcaneus & 2 & - & - & - \\
\hline $\mathrm{R}$ calcaneus & - & - & - & - \\
\hline L carpals* & $2 / 2$ & - & - & - \\
\hline $\mathrm{R}$ carpals* & - & - & - & - \\
\hline Unsided carpals* & - & - & - & - \\
\hline L metacarpals* & - & - & - & - \\
\hline $\mathrm{R}$ metacarpals* & - & - & - & - \\
\hline Unsided metacarpals* & $3 / 0$ & - & - & - \\
\hline L manual phalanges* & $4 / 0$ & - & - & - \\
\hline $\mathrm{R}$ manual phalanges* & - & - & - & - \\
\hline
\end{tabular}


Table B.1, continued

\begin{tabular}{l|c|c|c|c}
\hline Element & Burial 1 & Burial 2 & Burial 3** & Burial $3^{* * *}$ \\
\hline Unsided manual phalanges* & - & - & - & - \\
\hline $\begin{array}{l}\text { L tarsals (excluding calcaneus and } \\
\text { talus* }\end{array}$ & $3 / 3$ & - & - & - \\
\hline $\begin{array}{l}\text { R tarsals (exclusind calcaneus and } \\
\text { talus)* }\end{array}$ & $3 / 2$ & - & - & - \\
\hline Unsided tarsals* & - & - & - & - \\
\hline L metatarsals* & $5 / 0$ & $1 / 0$ & - & - \\
\hline R metatarsals* & $5 / 0$ & - & - & - \\
\hline Unsided metatarsals* & - & - & - & - \\
\hline L pedal phalanges* & - & - & - & - \\
\hline R pedal phalanges* & - & - & - & - \\
\hline Unsided pedal phalanges* & $4 / 0$ & - & - & - \\
\hline
\end{tabular}

Notes: L = left

$\mathrm{R}=$ right

Blank $=$ missing

$1=75-100 \%$ present; element largely complete and available for observation

$2=25-75 \%$ present; element partially complete and/or has reduced potential for observation

$3=<25 \%$ present; element badly eroded or very incomplete

(see Buikstra and Ubelaker 1994:6 for coding descriptions)

* = grouped elements; number present/number complete

$* *$ = adult

$* * *$ subadult 
Table B.2. Adult sex

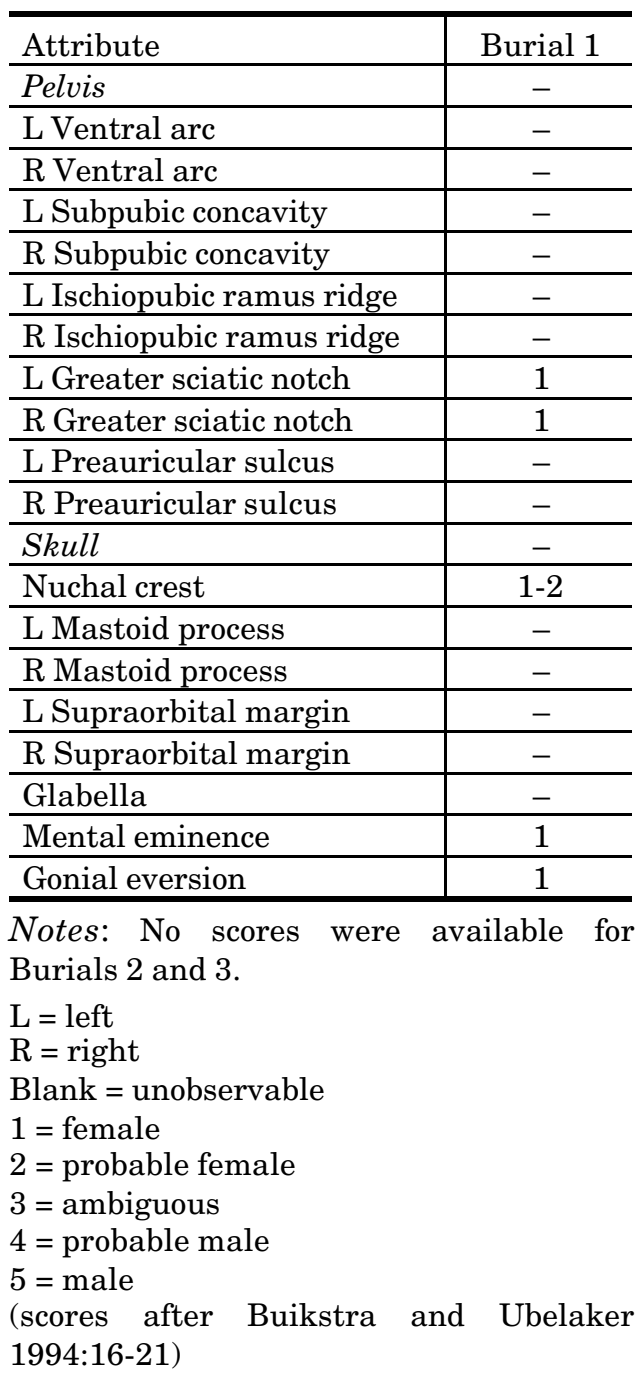


Table B.3. Adult age

\begin{tabular}{l|c}
\hline Age criteria & Burial 1 \\
\hline L Pubic symphysis Todd phase & - \\
\hline R Pub. symph. Todd phase & - \\
\hline L Pub. symph. Suchey-Brooks phase & - \\
\hline R Pub. symph. Suchey-Brooks phase & - \\
\hline L Auricular surface & - \\
\hline R Auricular surface & - \\
\hline Midlambdoid* & $1-2$ \\
\hline Lambda & - \\
\hline Obelion & - \\
\hline Anterior-Sagittal & - \\
\hline Bregma & - \\
\hline Midcoronal & - \\
\hline Pterion & - \\
\hline Sphenofrontal & - \\
\hline Inferior sphenotemporal & - \\
\hline Superior sphenotemporal & - \\
\hline Incisive** & $2-3$ \\
\hline Anterior median palatine & - \\
\hline Posterior median palatine & - \\
\hline Transverse palatine & - \\
\hline Sagittal (endocranial) & - \\
\hline L Lambdoid (endocranial) & - \\
\hline L Coronal (endocranial) & \\
\hline Notes: No scores wereavailable for Burals & \\
\hline
\end{tabular}

Notes: No scores were available for Burials 2 and 3.

$\mathrm{L}=\mathrm{Left}$

$\mathrm{R}=$ Right

Blank = unobservable

$0=$ open

$1=$ minimal closure

$2=$ significant closure

$3=$ complete obliteration

* = scores after Meindl and Lovejoy (1985)

** = scores after Buikstra and Ubelaker (1994:32) 
Table B.4. Postcranial measurements

\begin{tabular}{|c|c|}
\hline Measurement & Burial 1 \\
\hline Clavicle: maximum length & - \\
\hline Clavicle: A-P diameter at midshaft & - \\
\hline Clavicle: S-I diam. at midshaft & - \\
\hline Scapula: height & - \\
\hline Scapula: breadth & - \\
\hline Humerus: max. length & - \\
\hline Humerus: epicondylar breadth & - \\
\hline Humerus: vertical diam. of head & - \\
\hline Humerus: Max. diam. at midshaft & - \\
\hline Humerus: Min. diam. at midshaft & - \\
\hline Radius: max. length & - \\
\hline Radius: A-P diam. at midshaft & - \\
\hline Radius: M-L diam. at midshaft & - \\
\hline Ulna: max. length. & - \\
\hline Ulna: A-P diam. & - \\
\hline Ulna: M-L diam. & - \\
\hline Ulna: physiological length & - \\
\hline Ulna: min. circumference & - \\
\hline Sacrum: A length & - \\
\hline Sacrum: A S breadth & - \\
\hline Sacrum: max. transverse diam. base & - \\
\hline Os coxae: height & - \\
\hline Os coxae: iliac breadth & - \\
\hline Os coxae: pubis length & - \\
\hline Os coxae: ischium length & - \\
\hline Femur: max. length & - \\
\hline Femur: bicondylar length & - \\
\hline Femur: epicondylar breadth & - \\
\hline Femur: max. diam. of head & 43.89 \\
\hline Femur: A-P subtrochanteric diam. & - \\
\hline Femur: M-L subtrochanteric diam. & - \\
\hline Femur: A-P midshaft diam. & - \\
\hline Femur: M-L midshaft diam. & - \\
\hline Femur: midshaft circumference & - \\
\hline Tibia: length & - \\
\hline Tibia: max. proximal epiphyseal length & - \\
\hline Tibia: max. distal epiphyseal length & - \\
\hline Tibia: A-P. diam. at nutrient foramen & 29.68 \\
\hline Tibia: M-L diam. at nutrient foramen & 21.70 \\
\hline Tibia: circumference at nutrient foramen & 83.00 \\
\hline Fibula: max. length & - \\
\hline Fibula: max. diam. at midshaft & - \\
\hline Calcaneus: max. length & - \\
\hline Calcaneus: middle breadth & - \\
\hline
\end{tabular}

Notes: All measurements in millimeters. Measurements taken on left side. No measurements were possible for Burials 2 and 3.

Blank = not observable.

$\mathrm{A}=$ anterior

$\mathrm{P}=$ posterior

$\mathrm{S}=$ superior

$\mathrm{I}=$ inferior

$\mathrm{M}=$ medial

$\mathrm{L}=$ lateral 
Table B.5. Primary nonmetric traits

\begin{tabular}{|c|c|}
\hline Trait & Burial 1 \\
\hline Metopic suture & 0 \\
\hline L supraorbital notch & 9 \\
\hline $\mathrm{R}$ supraorbital notch & 9 \\
\hline L supraorbital foramen & 9 \\
\hline $\mathrm{R}$ supraorbital foramen & 9 \\
\hline L infraorbital suture & 9 \\
\hline $\mathrm{R}$ infraorbital suture & 9 \\
\hline L mult. infraorbital foramina & 9 \\
\hline $\mathrm{R}$ mult. infraorbital foramina & 9 \\
\hline L zygomatico-facial foramina & 9 \\
\hline R zygomatico-facial foramina & 9 \\
\hline $\mathrm{L}$ parietal foramen & 9 \\
\hline $\mathrm{R}$ parietal foramen & 9 \\
\hline L epipteric bone & 9 \\
\hline $\mathrm{R}$ epipteric bone & 9 \\
\hline L coronal ossicle & 9 \\
\hline R coronal ossicle & 9 \\
\hline Bregmatic bone & 9 \\
\hline Sagittal ossicle & 9 \\
\hline Apical bone & 9 \\
\hline L lambdoid ossicle & 0 \\
\hline R lambdoid ossicle & 9 \\
\hline L asterionic bone & 9 \\
\hline $\mathrm{R}$ asterionic bone & 9 \\
\hline L ossicle in occipito-mastoid suture & 9 \\
\hline $\mathrm{R}$ ossicle in occipito-mastoid suture & 9 \\
\hline L parietal notch bone & 9 \\
\hline $\mathrm{R}$ parietal notch bone & 9 \\
\hline Inca bone & 9 \\
\hline L condylar canal & 9 \\
\hline $\mathrm{R}$ condylar canal & 9 \\
\hline L divided hypoglossal canal & 9 \\
\hline $\mathrm{R}$ divided hypoglossal canal & 9 \\
\hline Flexure of superior sagittal sulcus & 9 \\
\hline L foramen ovale incomplete & 9 \\
\hline $\mathrm{R}$ foramen ovale incomplete & 9 \\
\hline $\mathrm{L}$ foramen spinosum incomplete & 9 \\
\hline $\mathrm{R}$ foramen spinosum incomplete & 9 \\
\hline L pterygo-spinous bridge & 9 \\
\hline $\mathrm{R}$ pterygo-spinous bridge & 9 \\
\hline L pterygo-alar bridge & 9 \\
\hline $\mathrm{R}$ pterygo-alar bridge & 9 \\
\hline L tympanic dihiscence & 9 \\
\hline $\mathrm{R}$ tympanic dihiscence & 9 \\
\hline L auditory exostosis & 9 \\
\hline $\mathrm{R}$ auditory exostosis & 9 \\
\hline $\mathrm{L}$ mastoid foramen location & 0 \\
\hline $\mathrm{R}$ mastoid foramen location & 0 \\
\hline L mastoid foramen number & 0 \\
\hline $\mathrm{R}$ mastoid foramen number & 0 \\
\hline
\end{tabular}


Table B.5, continued

\begin{tabular}{l|c}
\hline Trait & Burial 1 \\
\hline L mental foramen & 9 \\
\hline$R$ mental foramen & 9 \\
\hline L mandibular torus & 0 \\
\hline$R$ mandibular torus & 0 \\
\hline L mylohyoid bridge location & 9 \\
\hline$R$ mylohyoid bridge location & 9 \\
\hline L mylohyoid bridge degree & 9 \\
\hline$R$ mylohyoid bridge degree & 9 \\
\hline L atlas bridging-lateral & 9 \\
\hline$R$ atlas bridging-lateral & 9 \\
\hline L atlas bridging-posterior & 9 \\
\hline$R$ atlas bridging-posterior & 9 \\
\hline L accessory transverse foramina $(\mathrm{C} 7)$ & 9 \\
\hline$R$ accessory transverse foramina $(\mathrm{C} 7)$ & 9 \\
\hline L septal aperture & 9 \\
\hline$R$ septal aperture & 9 \\
\hline
\end{tabular}

Notes: No traits were observable for Burials 2 and 3.

$0=$ Absent

9 = Unobservable

See Buikstra and Ubelaker (1994:87-92) for

additional code definitions.

$\mathrm{L}=$ left

$\mathrm{R}=$ right

$\mathrm{C}=$ cervical vertebra 
Table B.6. Dental inventory, development, wear, and pathology of permanent teeth from Burial 1

\begin{tabular}{|c|c|c|c|c|c|c|c|c|c|}
\hline Tooth & Presence & Wear & Caries 1 & Abscess & Calculus & $\begin{array}{l}\text { Surface } \\
\text { affected }\end{array}$ & $\begin{array}{c}\text { Hypo. } 1 \\
\text { type }\end{array}$ & $\begin{array}{l}\text { Hypo. } 1 \\
\text { location }\end{array}$ & Other \\
\hline $\mathrm{R} \max . \mathrm{M} 3$ & 8 & - & - & - & - & - & - & - & - \\
\hline $\mathrm{R}$ max. M2 & 7 & - & - & 0 & 0 & - & - & - & - \\
\hline $\mathrm{R}$ max. M1 & 2 & 8 & 0 & 0 & 0 & 0 & 0 & 0 & 0 \\
\hline $\mathrm{R} \max . \mathrm{P} 2$ & 2 & $2-3$ & 0 & 0 & 0 & 0 & 0 & 0 & 0 \\
\hline $\mathrm{R} \max . \mathrm{P} 1$ & 2 & 2 & 0 & 0 & 0 & 0 & 0 & 0 & 0 \\
\hline $\mathrm{R} \max . \mathrm{C}$ & 2 & 3 & 0 & 0 & 0 & 0 & 0 & 0 & 0 \\
\hline $\mathrm{R} \max . \mathrm{I} 2$ & 1 & 3 & 0 & 0 & 0 & 0 & 0 & 0 & 0 \\
\hline $\mathrm{R} \max . \mathrm{I} 1$ & 3 & - & - & - & - & - & - & - & - \\
\hline L max. I1 & 1 & $3-4$ & 0 & 0 & 0 & 0 & 0 & 0 & 0 \\
\hline $\mathrm{L} \max . \mathrm{I} 2$ & 3 & - & - & - & - & - & - & - & - \\
\hline $\mathrm{L} \max . \mathrm{C}$ & 1 & 2 & 0 & 0 & 0 & 0 & 0 & 0 & 0 \\
\hline $\mathrm{L} \max . \mathrm{P} 1$ & 1 & $2-3$ & 0 & 0 & 0 & 0 & 0 & 0 & 0 \\
\hline $\mathrm{L} \max . \mathrm{P} 2$ & 2 & $2-3$ & 0 & 0 & 0 & 0 & 0 & 0 & 0 \\
\hline L max. M1 & 2 & 17 & 0 & 0 & 0 & 0 & 0 & 0 & 0 \\
\hline $\mathrm{L}$ max. M2 & 2 & 8 & 0 & 0 & 0 & 0 & 0 & 0 & 0 \\
\hline L max. M3 & 8 & - & - & - & - & - & - & - & impacted \\
\hline L mand. M3 & 8 & - & - & - & - & - & - & - & $\overline{\text { impacted }}$ \\
\hline L mand. M2 & 2 & 12 & 0 & 0 & 0 & 0 & 0 & 0 & 0 \\
\hline L mand. M1 & 2 & 20 & 0 & 0 & 0 & 0 & 0 & 0 & 0 \\
\hline L mand. P2 & 2 & 2 & 0 & 0 & 0 & 0 & 0 & 0 & 0 \\
\hline L mand. P1 & 1 & 2 & 0 & 0 & 0 & 0 & 0 & 0 & 0 \\
\hline L mand. C & 1 & $3-4$ & 0 & 0 & 0 & 0 & 0 & 0 & 0 \\
\hline L mand. I2 & 1 & $3-4$ & 0 & 0 & 0 & 0 & 0 & 0 & 0 \\
\hline L mand. I1 & 3 & - & - & - & - & - & - & - & - \\
\hline $\mathrm{R}$ mand. I1 & 3 & - & - & - & - & - & - & - & - \\
\hline $\mathrm{R}$ mand. I2 & 3 & - & - & - & - & - & - & - & - \\
\hline $\mathrm{R}$ mand. $\mathrm{C}$ & 1 & $3-4$ & 0 & 0 & 0 & 0 & 0 & 0 & 0 \\
\hline $\mathrm{R}$ mand. $\mathrm{P} 1$ & 1 & 2 & 0 & 0 & 0 & 0 & 0 & 0 & 0 \\
\hline $\mathrm{R}$ mand. $\mathrm{P} 2$ & 2 & 2 & 0 & 0 & 0 & 0 & 0 & 0 & 0 \\
\hline $\mathrm{R}$ mand. $\mathrm{M} 1$ & 2 & 12 & $1-2 ?$ & 0 & 0 & 0 & 0 & 0 & 0 \\
\hline $\mathrm{R}$ mand. M2 & 2 & - & 0 & 0 & 0 & 0 & 0 & 0 & 0 \\
\hline $\mathrm{R}$ mand. $\mathrm{M} 3$ & 8 & - & - & - & - & - & - & - & impacted \\
\hline
\end{tabular}

Notes: There were no teeth associated with Burials 2 and 3

$0=$ Absent

Blank = unobservable

See Buikstra and Ubelaker (1994:47-58) for additional code definitions.

$\mathrm{L}=$ left

$\mathrm{R}=$ right

Max. = maxillary

Mand. = mandibular

$\mathrm{I}=$ incisor

$\mathrm{C}=$ canine

$\mathrm{P}=$ premolar

$\mathrm{M}=$ molar 


